\title{
INTEREST ANALYSIS AND THE MYTH OF LEGISLATIVE INTENT
}

\section{Lea Brilmayer*}

Modern conflict-of-laws scholarship is the victim of a well-intentioned misrepresentation. Proponents of "governmental interest analysis" have marketed their theory as a species of legislative interpretation, indeed as the definitive approach to construing legislative intent. ${ }^{1}$ But while promoted by Brainerd Currie as an antidote to the pernicious metaphysical assumptions that afficted Beale and the First Restatement, ${ }^{2}$ interest analysis is in fact nothing of the kind. Interest analysis merely substitutes one set of metaphysical premises for another, leaving the body of conflicts law with a remedy every bit as distressing as the disease it was designed to cure.

Thus far, the interest analysts have been allowed to argue, in effect, "Our method may seem shortsighted and parochial, but it is not the courts' business to second-guess a state legislature." The avowed goal is precise, case-by-case implementation of state statutory policies - loyalty to state policy concerns rather than to "first principles" such as uniformity or predictability. By neglecting to challenge the interest analysts' claims of fidelity to legislative intent, ${ }^{3}$ tradition-

* Assistant Professor of Law, University of Chicago Law School. B.A. 1970, J.D. 1976, University of California at Berkeley; LL.M. 1978, Columbia University. -Ed. I would like to thank my research assistant, Brenda Lyons, as well as many colleagues, including David Currie, Doug Laycock, Bill Powers, Gary Simson, and Russell Weintraub. The Article arose out of a very valuable intellectual interchange with Professor Maurice Rosenberg, whose influence is evident throughout.

I. B. Currie, Selected Essays on the Conflicts of Law (1963) thereinafter cited as CURRIE ESSAYS] is the seminal work. "It is explicitly an attempt to determine legislative purposes. . . ." Id. at 727. "[T] he method I advocate is the method of statutory construction. . . "Id. at 627. In addition, see Currie, The Disinterested Third State, 28 LAw \& ConTEMP. Prob. 754, 760-61 (1963); Hancock, "In the Parish of St. Mary le Bow, in the Ward of Cheap" Choice-of-Law Problems Resolved by Statutory Construction: The Charitable Testa. mentary Gift Cases, 16 STAN. L. REv. 561 (1964). Currie once attempted to distinguish between "intention" and "purpose." The difference he saw is not altogether clear, although it may be the distinction proposed in the text below, between actual and constructive intent. He did concede that legislatures did not have any particular intent about how certain cases ought to be decided. 28 Law \& ConTemp. Prob. at 761-62.

2. Currie, The Disinterested Third State, 28 Law \& ContemP. Prob. 754 (1963). See also CURRIE EsSAYS, supra note 1, at 613: "Almost all constructive writing on conflict of laws in this century has been in revolt against this heritage . . . ."

3. One author who has disputed these claims is Professor Robert Leflar:

This process [of statutory construction] involves discovering in a statute something that the legislature did not put into it. . . . Even if called "statutory construction," this is really an independent and essentially extraneous process, depending on facts not cited in the statute itself and in the interests growing out of them. ... The term "statutory con- 
ally minded conflicts theorists have by implication left themselves espousing the proposition that a court should decline to honor valid legislative wishes. That posture is unnecessarily vulnerable, conceding the interest analysts far too much. This Article attempts to strip away the defense of mock judicial deference and to criticize governmental interest analysis on its own merits.

My critique begins with a brief analysis of the principles underlying the Currie school's calculations of whether a state has an interest in having its law applied; it seeks to expose the unarticulated biases inherent in that calculus. ${ }^{4}$ I then argue that Currie's principles cannot be justified as expressions of actual legislative intent regarding a statute's territorial scope. ${ }^{5}$ Indeed, the discrepancy between governmental interests and actual legislative intent has been overlooked only because, in the vast majority of cases, legislatures have no actual intent on territorial reach with which to contrast Currie's results.

But without actual legislative endorsement, interest analysis must fall back on constructive intent - on a theory that a rational legislature would, upon reflection, prefer the results of interest analysis to those of competing conflicts methodologies. ${ }^{6}$ In the most detailed discussion of this Article, I take issue with this theory. Interest analysis is simply too unpredictable and parochial to be a plausible theory of constructive intent. ${ }^{7}$ Furthermore, it is highly doubtful that substantive intent can by itself provide a sufficient basis for conflict of laws decisions. ${ }^{8}$ I conclude with a short survey of conflicts statutes to demonstrate that when legislatures treat conflicts problems explicitly, they ordinarily do not follow the interest analysts' approach to territorial reach.9 Interest analysis no more reflects actual or constructive legislative intentions than did the First Restatement. It is a metaphysical system, and a remarkably flawed one at that.

\section{The Calculus of Interests}

Any study of the method proposed by Brainerd Currie must be-

struction" is no more than a pretentious disguise for application of the court's conflicts law.

Leflar, Choice-of-Law Statutes, 44 TENN. L. REv. 951, 954 (1977). See also Reese, Conflicts of Laws and the Restatement Second, 28 LAw \& ContemP. Prob. 679, 686 (1963).

4. See text at notes 10-35 infra.

5. See text at notes 36-47 infra.

6. See text at notes 48-87 infra.

7. See text at notes 48-87 infra.

8. See text at notes 88-97 infra.

9. See text at notes 100-16 infra. 
gin with the concept of a "governmental interest." 10 An "interest" is, essentially, a prima facie claim that a state's law should apply. It is generally thought, for instance, that a forum's interest will trump the interests of other involved states because of the court's duty to follow legislative commands. ${ }^{11}$ And while other factors may override an interest, commentators disagree over when an interest should yield. For instance, some authorities believe that it is desirable to mediate conflicts between two or more competing interests by reexamining those interests. Closer examination may show one interest to be weightier than the other, ${ }^{12}$ one to be more consistent with modern trends in substantive law than the other, ${ }^{13}$ or one to be more jeopardized by neglect. ${ }^{14}$ But lengthening the process of accommodating and implementing those state interests already recognized will not remedy all defects inherent in the initial "identification" of interests. Among other things, injustice may result precisely because a state fails to find an interest; ${ }^{15}$ subsequent steps do not remedy this problem. For this reason, and because the identification of "interests" in theory determines whether the legislature would wish to have its law applied, "interest" is the key concept in the critical discussion below.

Whether a state is thought to have an interest in having its law applied to a particular case is a function of the multistate elements present in a case, the precise statutes involved, and the policies underlying those statutes. These policies can be categorized as protective, compensatory, and regulatory, for in drawing multistate implications from statutes, Currie relied upon their protective, compensatory, and regulatory aspects. His treatment of the married women's contract cases exemplifies the interest analyst's approach to a statute that furthers a protective policy. The court in Milliken $v$.

10. See CURRIE EsSAYS, supra note 1, at 189.

11. See, e.g., CurRIE EsSAYS, supra note 1, at 181-82, 610, 617.

12. Currie argued that a court should not weigh interests. See id. at 182, 606, 610, 617. Apparently, however, he thought balancing was intimated by the Second Restatement approach, which asked which contacts were "more significant." See also Currie, supra note 2, at 759 (criticizing Cavers's proposal to weigh interests to decide which is "greater").

13. Leflar thought that it was relevant to ask which rule of law was substantively more sound. See Leflar, Conficts Law: More on Choice-Infuencing Considerations, 54 CALIf. L. Rev. 1584 (1966). See also Weintraub, The Future of Choice of Law for Torts: What Principles Should Be Preferred?, 41 LAw \& ConTEMP. Prob. 146, 163 (1977).

14. Professor Baxter has espoused an approach based on "comparative impairment." See Baxter, Choice of Law and the Federal System, 16 STAN. L. REv. 1 (1963).

15. The parochialism problems which arise when the state fails to find an interest in assisting nonresidents are discussed in the text at notes 64-87 infra. Other problems, which arise when a court tries to limit the unpredictable application of forum law under interest analysis, are discussed in the text at notes 59-61 infra. 
Pratt ${ }^{16}$ had to choose between a Massachusetts statute invalidating married women's agreements to act as guarantors for their husbands' debts and a Maine statute that did not; Pratt, the defendant, had guaranteed her husband's credit. In an early article, Currie analyzed the possible relevance of four multistate elements: the place of contracting, the domicile of the defendant, the domicile of Milliken, the merchant who sought to enforce the agreement, and the location of the suit. ${ }^{17}$

Currie found the place of contracting irrelevant. ${ }^{18}$ Furthermore, if suit was brought in Massachusetts, the wife's domicile was the only important element. According to Currie, Massachusetts had enacted its law invalidating contracts for the protection of Massachusetts married women; it had no reason to invalidate an agreement by a woman from Maine, which had emancipated its married women. "Never mind, for the time being, exactly what we mean by 'Massachusetts' married women - whether citizens, domiciliaries, residents. For the sake of convenience, until we must decide that question, let us say that it is residence in Massachusetts that defines the ambit of the state's protective policy."19 Herein lies the first general principle of Currie's analysis: If a state has a protective policy, then its interest in applying its law depends upon the residence of the defendant. ${ }^{20}$ State protective policies are designed to benefit resident defendants alone. ${ }^{21}$

16. 125 Mass. 374 (1878).

17. Discussed in chapter two of his Selected Essays, Currie, Married Women's Contracts: $A$ Study in Conflict-of-Laws Method, in CuRRIE EsSAYS, supra note 1, at 77.

18. CURRIE ESSAYS, supra note 1, at 109: "To apply the law of the place of making would be to make the result in each case depend upon an irrelevant factor, determined by chance."

19. Id. at 86 (emphasis original).

20. This principle is illustrated also by Currie's attitude toward guest statutes, which are protective laws. See id. at 690-742. Objecting to New York's application of the Ontario guest statute in a case involving a New York defendant, he wrote, "Ontario has no interest at all in the application of its guest statute. . . . The guest statute expresses a policy for the protection of defendants. The defendant here, however, is not a citizen or resident of Ontario, he is a citizen of a state that holds him accountable for injuries to his guests." Id. at 724.

21. On several occasions, Currie qualified this rule by saying that Massachusetts should also invalidate the contract if the defendant's state invalidated such contracts. See, e.g., id. at 111-13. This qualification was apparently designed to limit the parochial effects of his theory and to thwart constitutional objections. Yet his compromise does nothing for the woman who is not from a state that invalidates married women's agreements; she is still treated differently from forum residents. Currie's compromise was not recognizing a forum interest in having its law applied so much as applying the protective law of the other state. CurRIE EsSAYS, supra note 1, at 113 (indicating that it is her home law which protects her). He still could not imagine that the Massachusetts legislature would care about anyone other than Massachusetts women. He also suggested that, even without the qualification deferring to the other state's protective law, his parochial plan would be a rational way to maximize interests and would be acceptable if "higher authority" need not be consulted. Id. at 89 . In his subsequent discussions of interests, he often did not mention the qualification. 
Compensatory interests are the second classification implicit in Currie's analytical approach. As we have noted, protective interests favor defendants and are keyed to the defendant's residence or domicile. Compensatory interests, in contrast, favor plaintiffs and are triggered by the plaintiff's residence. The nature of compensatory interests is demonstrated by Currie's treatment of Grant v. McAuliffe, ${ }^{22}$ in which an Arizona protective statute competed with a California compensatory statute. In Grant, a California car had collided with another California car in Arizona, and the administrator of a deceased driver's estate brought suit in a California court. Under Arizona law, no tort suit could begin after the death of the tortfeasor; California, however, allowed such actions to survive. The California Supreme Court held the California statute applicable and allowed the action to proceed to trial.

Currie applauded this result. ${ }^{23}$ Damages for personal injury, he argued, are intended to compensate the injured party. The California statute evidenced concern that if tort law did not provide compensation, the injured person would become a public charge. Thus it subordinated the interests of the tortfeasor's estate to the interests of the injured person and of the citizens at large who would pay for public assistance. As with protective policies, Currie asserted that this compensatory policy was intended to benefit only injured residents. $^{24}$

A compensatory statute, favoring the plaintiff in a particular case, may of course have effects beyond the confines of that case. The price it exacts from the defendant may make the conduct that caused the harm unprofitable. If the statute is in fact designed to change incentives by making previously profitable conduct too costly, it may evidence a regulatory policy as well as a compensatory one. Occasionally, protective statutes also regulate conduct; while a contributory negligence standard favors defendants, it is also supposed to discourage negligent activity by plaintiffs. Currie found these "conduct-regulating" interests - the third class implicit in his analysis of legislative policies - to be triggered by territorial con-

22. 41 Cal. $2 d$ 859, 264 P.2d 944 (1953).

23. CURRIE EsSAYS, supra note 1, at 132.

24. Id. at 144-45. Although he also said there might be an interest when the plaintiff was present in the state at the time of injury, he dropped this suggestion thereafter, presumably because it reinforced the "state of wrong" rule.

Currie applied a similar analysis to cases involving other compensatory statutes, such as the New York child support statute in Haag v. Barnes, 9 N.Y.2d 554, 175 N.E.2d 441, 216 N.Y.S.2d 65 (1961). In Haag, he asserted, New York had an interest in applying its law because the mother and child were New York residents. CurRIE EsSAYS, supra note 1, at 732. 
necting factors rather than domiciliary factors. The most significant territorial connection with the forum was presence of the complained-of activity, but sometimes one could find a connection in the possibility of foreseeable harm within the jurisdiction. ${ }^{25}$

When the sole purpose of the statute is to regulate conduct, its scope seems clearly limited to conduct with territorial connections. Currie mentioned traffic rules as obvious examples: "We all know that the rule of the road varies from place to place. It is perfectly apparent that the rule in New York is not intended to have any application to Saudi Arabia, but is designed solely to regulate traffic on the streets and highways of New York." $26 \mathrm{He}$ also cited Sunday blue laws. Discussing a Georgia case concerning a contract formed in Kansas on a Sunday, he argued that the Georgia law invalidating Sunday contracts had no rational application to transactions in Kansas:

Georgia invalidates domestic Sunday contracts because (A) the criminal laws of the state prohibit the pursuit of one's ordinary calling on that day, and (B) the courts have decided that, in addition to the penal sanctions provided by statute, a contract made in violation of the prohibition should be made unenforceable. But the Georgia court would hardly have taken the position that the parties, in entering into this transaction in Kansas, had committed an offense against the criminal laws of Georgia. ${ }^{27}$

As even Currie recognized, the reason Georgia would not want its Sunday blue laws to apply to contracts made in Kansas is that expectations are important in governmental efforts to influence conduct, and expectations are largely territorial.

Because statutes embodying only regulatory policies are so obviously territorial, their conflict of laws implications are rarely litigated. $^{28}$ Regulatory policies, however, are important in conflicts

25. Frequently in the text below, and solely for the purpose of convenience, it will be stated simply that conduct-regulating rules apply to activities within the state, and the qualification "or causing foreseeable harm there" will be omitted.

26. CURRIE EsSAY, supra note 1, at 58.

27. Id. at 59-60 (footnotes omitted).

28. One interesting example, however, is People v. One 1953 Ford Victoria, $48 \mathrm{Cal}$. 2d 595, 311 P.2d 480 (1957). California police had confiscated an automobile used for transporting narcotics, and the Texas mortgagor sought its return. Under California law the owner of a security interest had to inquire into the debtor's character in order to preserve that interest if the security was confiscated. Under Texas law, however, no such inquiries were necessary. The California court held forum law inapplicable.

In the absence of a plain legislative direction to the contrary, . . the statute cannot reasonably be interpreted as requiring such investigation when the sales are financed in other states and the vehicles are taken to California, not only without the knowledge of those financing the sales, but in violation of express contractual prohibitions. . .. A person financing the sale of an automobile in Texas for use exclusively in that state will look to the laws of Texas for the determination of his rights and duties. 
litigation because they are often joined with compensatory or protective policies in a single statute. Regulatory policies are triggered by territorial connecting factors, and protective or compensatory policies by domiciliary ones. The difficult issue, therefore, is what to do when a fact situation triggers one of the interests behind a statute but not the other. What, in other words, should be done when conduct within the state injures a nonresident or when a resident is hurt by conduct outside the state? Apparently, the interest analysts would answer that either the compensatory or the conduct-regulating interest is a sufficient reason to apply forum law. ${ }^{29}$ Thus, if the plaintiff is a resident or the tortious conduct occurred within the state, the state has an interest in having its statute applied. This is apparently the reason Currie would have allowed a New Yorker to benefit from New York negligence law even though the accident occurred out of the state: the New York compensatory interest was sufficient. ${ }^{30}$ Various cases purporting to apply interest analysis are consistent with this view, ${ }^{31}$ and it has been explicitly urged by at least one commentator. $^{32}$

Implicit in this calculus of interests are three discernible biases: pro-resident, pro-forum-law, and pro-recovery. The pro-resident bias results from the assumption that protective and compensatory policies of the forum can be invoked only by forum residents. Residents thus have the best of both worlds: they can claim the benefits of these policies in multistate cases without incurring the corresponding costs. The pro-recovery and pro-forum-law biases stem from the assumption that when a statute embodies several policies, any one of them may trigger the finding of an "interest." Thus, a forum statute that embodies regulatory and compensatory policies gives rise to a governmental interest if the plaintiff is a resident of the

48 Cal. $2 \mathrm{~d}$ at 598-99, 311 P.2d at 482 (citations omitted).

29. At least, when dealing with statutes evidencing both types of policies they seem content merely to cite one as justification for a finding of "interest." There seems to be no sentiment that if a court finds a compensatory policy, it should ask whether there are other policies involved and whether they are satisfied. See notes $59-61$ infra and accompanying text.

30. See CURRIE EsSAYS, supra note 1, at 725.

31. See, e.g., Brown v. Market Dev., Inc., 41 Ohio Misc. 57, 322 N.E.2d 367 (1974) (act providing civil damages held applicable where activity occurred within borders, even if nonresident defrauded); Johnson v. Spider Staging Corp., 87 Wash. 2d 577, 555 P.2d 997 (1976) (allowing unlimited wrongful death recovery on a deterrence theory); Kilberg v. Northeast Airlines, 9 N.Y.2d 34, 172 N.E.2d 526, 211 N.Y.S.2d 133 (1961) (allowing unlimited wrongful death recovery on a compensation theory).

32. "For purposes of interest analysis, a rule of substantive law should be presumed to reflect all legitimate policies that it could possibly serve." Sedler, The Governmental Interest Approach to Choice of Law: An Analysis and Reformulation, 25 UCLA L. REv. 181, 199 (1977) (emphasis original). See also Note, False Conflicts, 55 CALIF. L. Rev. 74, $76-78$ (1967) (state has an interest when one of a number of alternative grounds is satisfied). 
forum or if the offensive conduct occurred there. ${ }^{33}$ This splintering of policies increases the likelihood that the state will have an interest and predisposes the method toward forum law. Furthermore, it creates a bias toward recovery because pro-recovery statutes are the most likely to serve several different policies, namely compensatory and regulatory ones. The plaintiff's power to choose the forum contributes further to the pro-recovery bias; interest analysis permits different courts to reach different results by honoring their respective states' interests, and the plaintiff naturally selects the most favorable forum.

These biases do not bother the interest analysts too much, for the abiding purpose of their theory is case-by-case implementation of state policies. For members of the Currie school, deference to the laws of other jurisdictions and even-handed treatment of nonresidents do not warrant disregard of state substantive goals. ${ }^{34}$ Since they think "interests" are the perfect embodiment of legislative intent, the sacrifice of mundane system-coordinating concerns does not distress them. And if their premise is truly sound, their conclusion may be compelling; ${ }^{35}$ if interest analysis really holds the key to legislative intent, the sacrifice is not only worthwhile but arguably necessary.

\section{INTEREST ANALYSIS AND LEGISLATIVE INTENT}

Why do the interest analysts claim that their theory satisfies legislative desires? Saying it's so doesn't make it so. Most traditionally minded theorists would agree that any explicit legislative instructions should be followed; ${ }^{36}$ but the problem is what to do when the face of the statute is silent. What sort of evidence would interest analysts use to justify their inferences?

Currie did not envision extensive reliance upon legislative history. Many states do not even publish legislative histories, and those that do rarely document the legislators' views on territorial reach. Currie reached his solutions by generalizing about classes of statutes

33. This must include conduct which causes foreseeable harm within the jurisdiction. See note 25 supra and accompanying text.

34. Currie conceded that uniformity and protection of expectations were desirable, CuRRIE ESSAYS, supra note I, at 100-01, 186-87, but claimed that they did not justify substantial sacrifices of substantive interests. $I d$. at 118 (only where substantive policies weak).

35. One objection that might still be made is that many substantive law doctrines are judge made. If legislatures may specify the territorial reach of statutes as they please (within constitutional limits), courts should be equally free with common law. The policies are judicially created, and could be modified or overruled by later courts.

36. See, e.g., Restatement (SECOND) of Conflicts of LAws $\$ 6(1)$ (1971). 
(married women's contract laws, for instance), apparently assuming that unless otherwise indicated in the statute the policies behind all such statutes could be treated as identical. ${ }^{37}$ This assumption alone should make us suspicious about whether Currie was deducing true legislative intent, which one might expect to vary from state to state. It suggests that Currie's principles of inference were rather a product of his own normative beliefs about how far certain policies ought to reach.

Two pieces of evidence bolster this suspicion. The first is the willingness of Currie and his followers to criticize legislative choice when it contradicts the principles of interest analysis. Currie, for example, strenuously opposed efforts to change the result in Grant $v$. $M c$ Auliffe ${ }^{38}$ by legislation, writing that "a more mischievous piece of legislation . . . would be difficult to imagine."39 This is a strange posture for one who criticized traditional analysis for disregarding legislative preference. Currie apparently felt that legislatures should not participate in choice-of-law problems by expressing their wishes about the territorial reach of their statutes, at least not by enacting traditional rules.

[T]he California Legislature, and all others, would do well to avoid enacting choice-of-law rules in general. This is intended as a very narrow statement. It does not mean that legislatures should not concern themselves with problems of conflict of laws. There is a body of highly desirable legislation in the field. The statement means only that the legislature would be well advised not to express its will concerning conflict-of-laws problems in the form of traditional choice-of-law rules ....40

Since Currie did favor legislative action when it coincided with his views, ${ }^{41}$ what mattered to him was not whether the courts or the legislature should decide territorial reach, but whether the end result was application of interest analysis. Moreover, the interest analysts' willingness to criticize actual legislative choice manifests a conviction that a given statute has a "natural" territorial reach. This is, of

37. Currie did acknowledge that substantive law specialists should have the final say. CURRIE EsSAYS, supra note 1, at 592. But unless legislators give some indication of their wishes, there is nothing for such specialists to go on, and the courts facing conflicts problems are left speculating about types of statutes.

38. 41 Cal. 2d 859, 264 P.2d 944 (1953).

39. CURRIE EsSAYs, supra note 1, at 131 n.18.

40. Id. at 170. This seems particularly anomalous given that one supposed benefit of interest analysis is that it "invites legislative revision" if courts err. Id. at 604, 728. Currie was also opposed to legislatures adopting interstate treaties, on the ground that trading away the rights of state citizens was troubling. Id. at 121-22, 190 n.5. Apparently their role was to be limited to specifying the substantive policies involved, and letting the "natural law" of interest analysis take its course.

41. Id. at $171,114$. 
course, the familiar Bealean metaphysics in a new garb - although the content of the a priori principles has changed, they are a priori principles nonetheless.

The second piece of evidence that betrays the value-laden posture of interest analysis is Currie's promotion of the concept of "interest" as a constitutional test. Borrowing from Supreme Court decisions that chanced to use the word "interest" 42 before it became a term of art, Currie argued that the Constitution would be offended if and only if a court applied the law of a state without an interest. ${ }^{43}$ The significance of using the same term both to signify actual intent and to serve as a constitutional test is that the tests for actual intent and constitutionality are thereby equated. This jeopardizes the status of "interests" as actual intent, since to make actual intent dispositive of constitutionality would be to allow a state legislature to apply its law in its courts whenever it so desired. The legislature would need only to specify its intent clearly to create an "interest" and satisfy the Constitution. Indeed, since state courts are the final interpreters of state policies in our federal system, ${ }^{44}$ a test of actual intent would leave no federal question and, a fortiori, no jurisdictional basis for Supreme Court review. 45

But Currie clearly did not intend to repose such awesome discretion in the hands of state legislators when he described his constitutional test. He devoted a complete article to a discussion of the constitutional limits that interest analysis puts on legislative author-

42. Currie cites, for instance, Carroll v. Lanza, 349 U.S. 408 (1955); Watson v. Employers Liab. Assurance Corp., 348 U.S. 66 (1954); Pacific Employers Ins. Co. v. Industrial Accident Commn., 306 U.S. 493 (1939). CURRIE EsSAYS, supra note 1, at 145 n.64.

43. See CuRrie EsSAYS, supra note 1, at 188-282.

44. The Supreme Court has no" authority to correct state court errors in state law, even when there is an alternate federal basis for review. Murdock v. City of Memphis, 87 U.S. (20 Wall.) 590,635 (1875).

45. Another area in which interest analysis has served to confuse constitutional issues is full faith and credit, in which it is sometimes argued that a second state ought not to have to enforce the first state's judgments when to do so would be contrary to the second state's "interests." Magnolia Petroleum Co. v. Hunt, 320 U.S. 430, 419 (1943) (Douglas, J., dissenting); Brief of the Solicitor General's Office in Thomas v. Washington Gas Light Co., cert. granted, Docket No. 79-116, 48 U.S.L.W. 3356 (Nov. 26, 1979). Ordinarily, the second state's "interests" are irrelevant with regard to enforcement of sister-state judgments; Fauntleroy v. Lum, 210 U.S. 230 (1907) (no defense that gambling contract would have been held void as contrary to public policy); Milwaukee County v. White, 296 U.S. 268, 277 (1935) ("considerations of policy in the forum which would defeat a suit . . . are not involved"). See also Cheatam, Res Judicata and Full Faith and Credit, 44 Colum. L. Rev. 330, 336 (1944); R. Cramton, D. CURRIE \& H. KAY, CONFLICT OF LAWS 681 (2d ed. 1975) (state may not invoke public policy as a defense to enforcement of judgments).

If this test were adopted, and if "interest" is understood as actual intent, then, as with choice-of-law problems there would be no federal question. It is possible that proponents of this test mean "interest" as Justice Stone did; see cases cited in note 42 supra. The confusion of terms is extremely unfortunate and use of the word might best be abandoned. 
ity regarding choice of law. ${ }^{46}$ Thus, either he was intending to create a second constitutional type of interest analysis - and if he had such an independent theory he never developed it in print ${ }^{47}$ - or else "interests" do not involve actual intent at all.

Interest analysis must therefore be some species of constructive intent: a calculus of a priori principles that a court may fall back on when the legislature gives no guidance. Only if this conclusion is correct do interest analysts have a normative base from which to criticize conflicts statutes - for one's approach to constructive intent would probably be to choose what one finds to be the most coherent and convincing theory. This interpretation forces the interest analysts to concede that they reason from a priori assumptions, but at least it explains how they are able to draw inferences from a seemingly silent statute, like rabbits from a hat.

\section{CONSTRUCTIVE INTENT}

The law contains many maxims of statutory construction; penal laws, for instance, are supposed to be narrowly construed, as are statutes in derogation of the common law. If interest analysis is a plausible way of thinking about conflict-of-laws problems, it should be able to join those maxims as a basis for making inferences when no actual intent has been manifested. To avail itself of this opportunity, however, it must be convincing on its own merits, for it no longer has the legislative imprimatur. In this Section, I hope to demonstrate that the features that have made interest analysis unpalatable to many commentators - in particular, its unpredictability and parochialism - also leave it unconvincing as a species of constructive intent.

\section{A. Unpredictability}

Opponents of interest analysis have frequently objected that the theory allows unpredictable results:48 that persons who act in reliance on one state's laws may be unfairly surprised by application of another's. One cause of this unpredictability is the assumption that

46. See Currie, The Constitution and the Choice of Law: Governmental Interests and the Judicial Function, 26 U. CHI. L. REV. 9, 43-44, 75-76 (1958), reprinted in CURRIE EsSAYS, supra note 1 , at $232-33,271$.

47. His constitutional discussion follows and refers back to the nonconstitutional discussion, without offering a second definition of "interest." But see note 21 supra.

48. See, e.g., Hill, Governmental Interest and the Conflict of Laws - A Reply 10 Professor Currie, 27 U. CHI. L. Rev. 463, 463, 503-04 (1960) (interest analysis too "ad hoc"); Reese, Choice of Law: Rules or Approach, 57 CORNELL L. REv. 315 (1972) (rules allow predictability, an obvious benefit, but "approach" does not). 
when a statute evidences both a regulatory policy and a compensatory or protective policy, either would suffice to justify application of forum law..$^{49}$ Thus, a statute that embodies a strong regulatory policy together with a compensatory policy may be applied on the ground that the plaintiff is a forum resident, a fact that the defendant might well have been unable to ascertain at the time of conduct. This is problematic, since in enacting a regulatory statute a legislature manifests a belief that most people will change their behavior in contemplation of the law. It seems unjust to apply such a law to persons who could have had no notice of the applicable standards, since the legislature could not have expected them to change their conduct to conform. The resulting unfairness can be demonstrated by two hypothetical situations.

Dram-shop acts are statutes that prohibit the sale of liquor to inebriates; some states have interpreted them also to authorize recovery of civil damages from the tavern owner if the inebriate negligently injures someone later. ${ }^{50}$ It seems clear under interest analysis that dram-shop acts, so interpreted, embody both regulatory and compensatory policies. The compensatory policy seems implicit in the reasoning courts have used to justify imputing civil liability. ${ }^{51}$ The regulatory policy is evident both because the statutes make sale of liquor to inebriates illegal and because presumably anyone, resident or nonresident, could sue a tavern owner who made such a sale within the state. 52

If either of the two policies is a sufficient basis for applying a dram-shop act, then civil liability is appropriate whenever the sale occurs within the state or a state resident is injured. Interest analysis would thus seem to imply that if while on vacation in a state with no dram-shop act, a forum resident is hit by an auto careening out of a local bar's parking lot, then he may return home, sue, and recover from the tavern owner. There may be interest analysts who would

49. See text at notes 29-32 supra.

50. See, e.g., the statutes involved in Bernhard v. Harrah's Club, 16 Cal. 3d 313, 546 P.2d 719, 128 Cal. Rptr. 215, cert. denied, 429 U.S. 859 (1976); Graham v. General U.S. Grant Post, 43 Ill. 2d 1, 248 N.E.2d 657 (1969).

51. See Vesley v. Sager, 5 Cal. 3d 153, 486 P.2d 151, 95 Cal. Rptr. 623 (1971). But see Hamon v. Carson City Nugget, Inc., 85 Nev. 99, 450 P.2d 358 (1969). The reasoning in Bernhard v. Harrah's Club, 16 Cal. 3d 313, 546 P.2d 719, 128 Cal. Rptr. 215, cert. denied, 429 U.S. 859 (1976), which relied upon the plaintiff's California residence, strongly suggests that the California dram shop act as extended by $V$ esley demonstrated an interest in resident plaintiffs.

52. But see Graham v. General U.S. Grant Post, 43 Ill. 2d 1, 248 N.E.2d 657 (1969).

Interest analysts cannot explain nonresident recovery under dram-shop acts by compensatory policies. Rather the explanation must be that it is desirable to discourage all sales of this sort, since the tavern owner had no way of knowing that a mere resident would be injured. 
not flinch at this result, since the forum has an "interest" in seeing its plaintiff compensated. These theorists would not mind that the tavern owner was surprised by application of forum law, since state courts are not in business to take pity on dismayed nonresidents, but rather to do as their legislature bids. The legislative command, presumably, is "Thou shalt compensate forum residents."

A second hypothetical, however, indicates that residents, too, may be trapped by the interest analysts' logic. Assume that the forum legislature has learned that installing a special safety guard would reduce the number of accidents caused by power lawn mowers. It orders manufacturers to install the guard on all new mowers and provides that noncompliance shall be negligence per se. A resident manufacturer diligently complies when manufacturing lawn mowers to be sold within the state. The safety guard is expensive, however, and he decides not to put himself at a competitive disadvantage by installing them on mowers he manufactures for sale and use in other states. "After all," he reasons, "my state legislature would have no desire to regulate my sales in other jurisdictions. That's interstate commerce." 53 Will the forum nevertheless apply the negligence per se provision if the person injured in an out-ofstate accident turns out, coincidentally, to be a resident? It is unlikely that an interest analyst scholar or a court would go so far. But if not, why not?

Traditional theory would have no problem with this case, since one of its goals was predictability, and a foreseeability test would preclude the law's application to situations where reliance upon another state's law was this likely. Interest analysts, however, are not noted for their fondness for foreseeability tests. ${ }^{54}$ They would probably prefer something other than an across-the-board foreseeability test to explain why the supposed compensatory policy should not be honored. The interest analysts might, for instance, assert that when

53. But cf. Sligh v. Kirkwood, 237 U.S. 52 (1915) (statute penalizing sale of shipping of unripe citrus fruit valid as applied to interstate commerce, despite argument that state had no valid concern for health of persons in other states). See also Brown v. Market Dev., Inc., 41 Ohio Misc. 57, 322 N.E.2d 367 (1974). In some cases, a legislature may desire to prohibit any manufacture within the state, regardless of the place of sale. In the hypothetical example this seems unlikely and the manufacturer's inference seems reasonable. The rationale for Brown was that fraud within the state remained fraud regardless of the fact that it was directed against outsiders: The rationale in Sligh was that the state had a right to protect the reputation of its citrus products.

54. Currie, as noted earlier, did concede predictability to be a virtue, but did not find that it warranted sacrificing substantive interests. See note 34 supra. One commentator who has emphasized both analysis of interests and foreseeability is Professor Russell Weintraub. $\mathbf{R}$. Weintraub, Commentary on the Conflict of Laws 208-10 (1971). For Leflar's choiceinfluencing considerations, see Leflar, supra note 13. 
a statute has a significant regulatory purpose, then the statute is not designed to be triggered by domiciliary factors, except perhaps when the plaintiff's residence is known at the time of conduct. In other words, satisfaction of the regulatory policy would be a necessary precondition to assertion of the concurrent compensatory interest.

No doubt, this accommodation to foreseeability would be an improvement. It could, furthermore, be readily subsumed under either a "comparative impairment" or a "moderate and restrained interpretation" approach to interest analysis. ${ }^{55}$ But interest analysts who find themselves sympathetic to such an accommodation should ask whether a more radical revision is not in order. In particular, this strategy suggests that there are dangers in merely spotting a compensatory interest in a case with a resident plaintiff and then applying forum law. A concern with foreseeability makes it important to ask whether the statute does not also embody a regulatory policy and, if it does, whether that policy also gives rise to an interest.

It is easy to think of situations where this question should have been asked. With married women's contract statutes, it seems reasonable to impute to the legislature an awareness that merchants would not enter into unenforceable contracts. It also seems reasonable to assume that the legislature deliberately intended to discourage merchants from the overreaching that such contracts were conclusively presumed to demonstrate. In fact, many of the statutes that interest analysts call protective or compensatory alter incentives in a way that suggests that the legislature was aware of, and probably approved of, their regulatory effects. ${ }^{56}$ Treating married women's contract statutes as protective rather than regulatory seems arbitrary - they are both. Limiting concern to a statute's protective aspects is reminiscent of the Bealean system's arbitrary process of characterization, which Currie deplored. 57

Moreover, recognizing that satisfaction of a regulatory purpose is a necessary condition to application of a law with both regulatory

55. See articles cited in notes 12-14 supra.

However, it would be preferable to accommodate foreseeability in the initial stages of interest determination rather than merely taking a sober second look once a conflict was identified. If the foreseeability test is delayed until this latter stage, it may never be brought to bear since the other state may not have an "interest" under Currie's definitions.

56. Spendthrift trust statutes may influence conduct, but see Lilienthal v. Kaufman, 239 Or. 1, 395 P.2d 543 (1964); so also may vicarious liability statutes for loan of automobiles, which also have the compensatory purpose of providing a solvent defendant, see Young v. Masci, 289 U.S. 253 (1933) (upholding application of New York vicarious liability law after foreseeability analysis); Levy v. Daniels' U-Drive Auto Renting Co., 108 Conn. 333, 337, 143 A. 163, 164 (1928) (vicarious liability statute provides incentive to person renting vehicle to rent only to competent and careful drivers).

57. CURRIE EsSAYS, supra note 1, at 133. 
policies and compensatory or protective policies means that, for such statutes, domiciliary factors are completely irrelevant. The reason is that interest analysts seem to feel that the regulatory purpose is also a sufficient condition..$^{58}$ If this is true, then Currie's theory has made significant concessions to territorialism, which emphasized predictability and looked ordinarily to the places where the conduct at issue occurred while disregarding unpredictable domiciliary factors. Returning to the problem of dram-shop acts, and to an actual case decided according to Currie's principles, it is clear that treating the regulatory interest as both necessary and sufficient would require significant departures from the Currie school's analysis.

The case is Bernhard v. Harrah's Club. ${ }^{59}$ In Bernhard, a Nevada casino owner sold liquor to a patron who then drove into California and collided with a Californian on a motorcycle. In using interest analysis to apply the California dram-shop act, the California Supreme Court emphasized the plaintiff's California residence, as well as the foreseeability of application of California law. The Court found that the California statute embodied a regulatory policy and that "[d]efendant by the course of its chosen commercial practice has put itself at the heart of California's regulatory interest, namely to prevent tavern keepers from selling alcoholic beverages to obviously intoxicated persons who are likely to act in California in the intoxicated state." 60

Given such a finding, however, it is difficult to see the relevance of the plaintiff's California residence or even the California location of the accident. All of the facts that triggered the regulatory interest would also be present if the patron had happened to collide with a nonresident in California - or, for that matter, with a Nevada resident in Nevada. Perhaps the answer is that both regulatory and compensatory interests must be present before a court applies forum law: recovery only if a resident plaintiff is struck by an inebriate driving foreseeably through California. But this rule would prevent application of California law where the sale and accident occur there, but a nonresident is hurt. It is hard to believe that the interest analysts would wish that result, especially since the California stat-

58. See text at notes 29-32 supra.

59. 16 Cal. 3d 313, 546 P.2d 719, 128 Cal. Rptr. 215, cert. denied, 429 U.S. 859 (1976).

60. $16 \mathrm{Cal}$. 3d at 322,546 P.2d at $725,128 \mathrm{Cal}$. Rptr. at 221 . One possible test to explain this result, which would match the rationale fairly well, while avoiding the problems outlined in the text, would be to ask whether there was a foreseeable injury within California, disregarding the actual residence of the plaintiff. This probably places too much emphasis on foreseeability and location of the accident, and too little on "compensatory" interests to please the interest analysts. 
ute was presumably intended to regulate all sales inside the state by making such sales illegal.61

These examples illustrate some basic points about the value of predictability. First, predictability is crucial where the statute regulates conduct. If a state court believes that its state's statutes can be triggered by the location of conduct, it imbues the statute with a regulatory purpose. All unforeseeable applications should then be foreclosed. Second, if there is no way of determining in advance whether particular conduct will be covered by a statute, residents and nonresidents alike are put to a difficult choice between forgoing conduct that may later turn out to have been permissible and risking sanctions. This is the typical "vagueness" problem: a statute with uncertain boundaries discourages permissible conduct if people are aware of the possible penalties. And if they are unaware of the penalties because the possibility of applying the statute seems too remote, then application surprises individuals after the fact. ${ }^{62}$ Third, it is simply inefficient to govern activity through the in terrorem effect of overly broad laws. Regulations that are applied on an unpredictable basis impose costs that cannot be justified by social necessity, since by hypothesis they discourage conduct needlessly. The additional cost of lawnmower safety shields illustrates this inefficiency. Surely all concerned are better off if there is a predictable basis for deciding which lawnmowers need shields: the forum obtains its safe product; people in other jurisdictions can buy cheaper lawnmowers; and manufacturers are not put to the cost of installing shields on all mowers. ${ }^{63}$

61. 11 Cal. 3d 574, 522 P.2d 666, 114 Cal. Rptr. 106 (1974). See also Johnson v. Spider Staging Corp., 87 Wash. 2d 577, 555 P.2d 997 (1976).

62. See Amsterdam, The Void-for-Vagueness Doctrine in the Supreme Court, 109 U. PA. L. REv. 67 (1960).

It is an inadequate response to say that in a mobile society like our own, application of any state's law is foreseeable. This position would require every individual in the United States to ascertain and conform his conduct to the most stringent of the fifty states' laws, regardless of whether there is any apparent connection between that state and the conduct. It would give any state the right to regulate any conduct it wished merely by announcing that it intended its law to apply. The problem is reminiscent of the fourth amendment test of "reasonable expectations of privacy" established in Katz v. United States, 389 U.S. 347 (1967). The test is not only one of actual expectations, since the government might condition expectations by announcing a far-reaching wiretap program, just as a state might declare an intent to apply its law to all cases tried in its courts. Instead, it includes normative elements of what an individual ought to have to expect. See Smith v. Maryland, 99 S. Ct. 2577, 2580 n.5 (1979). See also Hague v. Allstate Ins. Co., No. 47874 (Minn. Aug. 19, 1979), cert. granted, No. 79-983, 48 U.S.L.W. 3535 (1980) (finding that automobile insurance companies accept the risk that insured may be subject to the law of states other than where the policy was written); World-Wide Volkswagen Corp. v. Woodson, 48 U.S.L.W. 4079 (1980) (insufficient contacts for personal jurisdiction that automobile sold by defendants would predictably be driven into other states).

63. The forum with the plaintiff-favoring rule may be able to effectuate its policies without making concessions to other states, although this would still leave the problem of surprising 


\section{B. Parochialism}

A second objection to the interest analysts' methodology is its parochialism, for interest analysis assumes that protective and compensatory policies are intended to benefit residents alone. The consequences of such an assumption are scarcely even-handed. For example, suppose the forum has an automobile guest statute - one requiring a passenger to demonstrate reckless or willful misconduct in order to recover from a host driver. Interest analysis holds that in a negligence action brought by a passenger who is a resident of the forum, a nonresident driver cannot claim the benefit of forum law and require a showing of reckless or willful misconduct. If, however, the nonresident had been the passenger and the resident had been driving, the forum would have an "interest" in applying its guest statute. The out-of-stater must pay if he is the driver but cannot collect if he is the passenger.

Limiting the reach of protective and compensatory statutes to precisely those cases where they benefit residents can lead to other obnoxious results. Suppose, for example, that state $A$ has a statute of frauds provision: according to interest analysis, it was designed to protect the residents of $A$. Anderson, a merchant from state $A$, contracts with Becker from state $B$; the contract does not satisfy $A$ 's statute of frauds, but under the law of $B$ it would be binding. Suppose Anderson wants to know if the contract is valid in state $A$. An interest analyst could not give a straight answer. The contract could be either valid or invalid since $A$ 's "interest" in having its statute of frauds applied depends upon which party is seeking to enforce the contract. If Anderson is suing Becker, then $A$ has no interest in supplying a protective defense. If, on the other hand, Becker sues Anderson, state $A$ will have an interest in asserting its statute of frauds on his behalf. State $A$ has, in effect, given its residents the power to

forum defendants. Otherwise all jurisdictions might achieve their goals better by specifying the law governing each case. Furthermore, although Currie disparaged the search for uniformity of result as comparable to a psychological need to make all substantive laws identical, precisely the opposite is true. Diversity of laws is protected when one state cannot undercut another's rules of conduct. If unlimited forum-shopping were allowed, only states with plaintiff-favoring rules would be able to enforce their standards.

Currie pointed out that, even if uniformity were important, no state could unilaterally attain it. See CurRIE EsSAYS, supra note 1, at 178-79. A state might sacrifice its interests only to have other states selfishly pursue their own. This demonstrates an important function that documents such as the Restatement should, ideally, fulfill. By coordinating expectations through suggesting voluntary compliance with known standards, the Restatement could induce cooperation by making it more likely that other states will reciprocate. As Schelling has argued, where all parties stand to gain through cooperation, but have no mutually binding way to agree, it may be sufficient that a third party suggest a compromise which focuses the necessary coordination. See T. Schelling, The Strategy of Conflict (1960). 
bind parties from out of state to a contract without being bound themselves. ${ }^{64}$

In other situations, faithful adherence to interest analysis would require a court to browse through the laws of the states involved in the controversy to pick the one that best served the resident party. Assume that Anderson is injured by a toy designed and manufactured by Billings in state $B$. Anderson thinks Billings was negligent in designing the product. An $A$ statute provides tort compensation for damages from negligent manufacture, which has been interpreted to include defective design. Does $A$ have an interest in having its law applied? As in the previous example, the answer must be "it depends." If $B$ law excludes recovery for defects in design, then $A$ has an interest in securing compensation for Anderson under its own law, for $A$ 's law appears to have a compensatory purpose that makes it applicable to help Anderson. But if $B$ is a strict liability state with no exclusion for design defects, $A$ 's interest would vanish since it is no longer to Anderson's advantage that $A$ law apply. ${ }^{65}$ In comparison to strict liability, a negligence system appears designed to protect manufacturers, and in this case the manufacturer is from out of state. "Interest" under the Currie approach amounts to an "interest" in getting the best deal possible for the resident party by choosing the most favorable law. ${ }^{66}$

The difficulty with Currie's approach is not its reference to domiciliary factors. If a state declared that its products liability law ap-

64. This bears a superficial resemblance to the Uniform Commercial Code statute-offrauds provision, which makes a contract enforceable only against the party who signed the writing. That rule, however, has an obvious evidentiary explanation.

65. Or at least some courts have so reasoned when forced to choose between forum negligence law and a strict liability law of the state of manufacture. See, e.g., Foster v. Day \& Zimmerman, 502 F.2d 867 (8th Cir. 1974).

66. Selective browsing through the statute books and case reports, to compile the most advantageous package for the resident party, is implausible given the factual assumptions underlying protective statutes. Legislatures enact guest statutes to prevent fraudulent claims against defendant drivers and their insurers. These statutes codify the legislative determination that host/guest claims are so likely to be fabricated that the forum should not honor them without proof of gross negligence. Currie assumed that the legislature would want a guest statute to benefit resident drivers only; if the driver was from a state without a guest statute, Currie would allow a resident plaintiff to recover. See text at note 30 supra. But it is not reasonable to believe that claims against nonresident drivers are less likely to be fabricated than claims against resident drivers. Interest analysis thus seems to impute to the guest statute state's legislature the rather cynical position that its courts should enforce fraudulent claims when the defendant is a nonresident. Since similar legislative determinations underlie other protective statutes (married women's laws or the statute of frauds, for instance), sensitive analysis of legislative history might lead courts to apply such statutes in all cases involving a forum cause of action, not just those with resident defendants. This solution would be akin to the traditional one of characterizing the issue as procedural. In the alternative, a court might limit application of the forum's guest statute out of some sentiment, such as comity, unrelated to what the court perceived as the substantively appropriate result. 
plied to all injured residents, the problem outlined above would be avoided. Either there would be an interest or there would not, and it would not depend upon comparison with other states' laws. But such a statute would not always benefit forum residents. It would benefit them in some cases and harm them in others. Thus, such a rational statute is irreconcilable with the superficially plausible syllogism that seems to underlie Currie's approach: if a statute is designed to benefit forum residents, it should be applied only when a resident will benefit.

Why should a court accept the suggestion that protective and compensatory policies should be applied only when a forum resident will benefit? The blatant parochialism evidenced by these examples surely imposes costs. It jeopardizes a principle essential to smooth functioning of federal systems: treating nonresidents as fairly as residents. ${ }^{67}$ It also raises difficult problems of whether an individual ought to be able to get a change of law by deliberately acquiring a

67. Some courts have justifiably balked at carrying this parochialism to its ultimate conclusion. See, e.g., Frummer v. Hilton Hotels, Intl., Inc., 19 N.Y.2d 533, 227 N.E.2d 851, 281 N.Y.S.2d 41, cert. denied, 389 U.S. 923 (1967), where a New York court rejected an argument that England had no interest in applying its comparative negligence rule merely because the plaintiff was from New York and the defendant from England. While denying that English law served a regulatory purpose, the Frummer court nevertheless gave the New Yorker the benefit of the more lenient standard of recovery:

With regard to the compensatory policy of the comparative negligence statute, it may be contended that, since the plaintiff is a New York resident, England might well prefer New

York law, which would benefit its domiciliary in this case. But it is difficult to conceive of England having such a parochial viewpoint. The statute by its language is not limited to any particular class of plaintiffs.

Concededly, the New York court may have been influenced in its decision to apply English law broadly by the New York residence of the beneficiary even though it purported to be analyzing English interests.

In McCrossin v. Hicks Chevrolet, Inc., 248 A.2d 917 (D.C. Ct. App. 1969), however, a District of Columbia court rejected a similar argument calling for application of Maryland's privity-of-contract doctrine to a Maryland resident. "The rule in the District," the court explained, "dispensing with the requirements of privity in implied warranty cases, is for the benefit and protection of all who buy in the District, not for residents of the District alone." 248 A.2d at 921 . Cf. Gravina v. Brunswick Corp., 338 F. Supp. 1 (D.R.I. 1972) (where the court found the interests of the state of plaintiff's residence and the state of defendant's principal place of business equivalent and therefore applied the "better" rule of law). The obvious problem with the Frummer strategy is that if there is an interest when the plaintiff is a resident, but we prefer not to treat nonresidents differently, then the law is applicable to all cases.

Another way of avoiding limiting compensatory statutes is by discovering a simultaneous regulatory interest. See, e.g., Hurtado v. Superior Court, 11 Cal. 3d 574, 522 P.2d 666, 114 Cal. Rptr. 106 (1974), in which a resident of Zacatecas, Mexico, was killed in an automobile accident in California by a California resident. The California Supreme Court held that California had an interest in applying its unlimited recovery rules, because unlimited damages deterred negligent driving:

It is manifest that one of the primary purposes of a state in creating a cause of action in the heirs for the wrongful death of the decedent is to deter the kind of conduct within its borders which wrongfully takes life. ... It is also abundantly clear that a cause of action for wrongful death without any limitation as to the amount of recoverable damages strengthens the deterrent aspect of the civil sanction . . . . Therefore when the defendant is a resident of California and the tortious conduct giving rise to the wrongful death action 
new domicile after the transaction in question occurs. ${ }^{68}$ Moreover, these costs might easily be avoided through a more comprehensive investigation of legislative intent, one that projects into the legislative mind some sensitivity to system-coordinating values. There are four possible justifications for the pro-resident bias of interest analysis: an analogy to welfare, protection of state resources, the nonresident's consent to his own state's laws, and pure favoritism.

It has been urged that restricting the benefits of forum law to residents is just like restricting the payment of welfare payments to residents. One author claims, "[A] state is interested in having its tort law applied to implement the compensatory policy reflected in that law in the same manner as it would be interested in applying its social insurance law."69 This analogy fails, however, because tort compensation is not state largesse; it is paid by private individuals. ${ }^{70}$ The funds for welfare, medical benefits, and unemployment insurance are amassed from state residents, and only those who could be required to contribute are eligible to make claims on the available money. Similarly, low tuition at state universities has been limited to residents because only residents support state universities through

occurs here, California's deterrent policy of full compensation is clearly advanced by application of its own law.

11 Cal. 3d at 583-84, 522 P.2d at 672, 114 Cal. Rptr. at 112 (citations omitted). While this reasoning has some appeal, the problems arising when concurrent regulatory interests are found are discussed in the text at notes 48-63 supra.

Confusion prevailed in Labree v. Major, 111 R.I. 657, 306 A.2d 808 (1973), which applied Rhode Island negligence law despite the guest statute of the state where the accident occurred. The court found that Rhode Island had an interest in holding its citizens to its own standard of care, and that there was no problem of unfair surprise because "no driver alters his manner of driving when he crosses into a state which holds him to a lesser degree of care towards his passenger." 111 R.I. at $67 \mathrm{I}, 306 \mathrm{~A} .2 \mathrm{~d}$ at 817 . The court should have been consistent: negligence law either influences behavior, or it does not.

68. After-acquired domicile is a difficult problem for Currie's theory, and one which is likely to become more frequent. See, e.g., Hague v. Allstate Ins. Co., cert. granted, No. 79-938, 48 U.S.L.W. 3535 (Feb. 19, 1980); cf. Rush v. Savchuk, 100 S. Ct. 580 (1980) (declaring unconstitutional Minnesota's assertion of quasi in rem jurisdiction over defendant; plaintiff moved to Minnesota after the accident that prompted the suit).

Currie argued that a state should be able to limit application in cases of after-acquired domicile. See CurRIE EsSAYS, supra note 1, at 620-21, 644. His explanation based upon "vested rights" seems peculiar in a theory decrying the metaphysics of the First Restatement.

An interesting question is the likely effect of the durational residency requirement cases on after-acquired domicile should Currie's residency test be universally explained as social welfare. Shapiro v. Thompson, 394 U.S. 618 (1969), held that discouraging migration into the state through waiting periods for welfare eligibility was an impermissible restriction on the right to travel. If application of state tort law is comparable to social insurance, then forum shopping through change of domicile might be equally protected in the conflicts setting.

69. Sedler, supra note 32, at 192.

70. Cf. Magnolia Petroleum Co. v. Hunt, 320 U.S. 430, 442 (1943) (full faith and credit case, "no constitutional question would be presented if Louisiana chose to be generous to the employee out of the general funds in its Treasury"). 
taxes. ${ }^{71}$ In contrast, when an interest analyst finds a compensatory policy in a multistate case, only in-staters are entitled to collect and only out-of-staters are required to pay. The result is a windfall to residents involved in multistate accidents: a benefit without a corresponding burden. ${ }^{72}$

In a related vein, Currie justified his parochial view of compensatory policies by suggesting that they are enacted to minimize the drain on state welfare funds. ${ }^{73}$ Presumably, nonresidents would never drain such funds. ${ }^{74}$ This rationale exemplifies a problem with Currie's methodology that interest analysts have never adequately faced. Currie seems to have been suggesting that the plaintiff's residence could be used as a proxy for other legislative concerns, such as the likelihood that the plaintiff would be thrown back upon public assistance or would default on local medical bills, thus harming the interests of local creditors. The domiciliary factor would, under this rationale, not be important in and of itself. But obviously, there will be some cases in which the plaintiff is wealthy enough that eventual recourse to welfare is unlikely. Should one nevertheless treat residence as conclusive? Or should one look beyond the plaintiff's residence to the presence or absence of these true concerns?

Currie vacillated on this issue, ${ }^{75}$ but appeared to conclude that

71. A state university today is an establishment with capital costs of many millions of dollars of investment. Its annual operating costs likewise may run into the millions. Parents and other taxpayers willingly carry this heavy burden because they believe in the values of higher education. It is not narrow provincialism for the State to think that each State should carry its own educational burdens. Until we redefine our system of government - as we are free to do by constitutionally prescribed means - the States may restrict subsidized education to their own residents.

Vlandis v. Kline, 412 U.S. 441, 459-60 (1973) (Burger and Rehnquist, JJ., dissenting). Since the majority opinion invalidated a presumption regarding out-of-state residency, it would, $a$ fortiori, have been sympathetic to the argument expressed in the text.

72. In some cases, if application of forum law is predictable, then residents bear a burden which makes the benefit fair. For example, in the married women's contract cases the statute imposes a disability as well as a benefit, since married women will be unable to enter into such contracts even if they want to. There is a benefit without a burden if and only if the merchant is unable to distinguish which women are residents, and thus deals with all women.

73. CuRRie EsSAYS, supra note 1, at 61. Currie, of course, realized that not every plaintiff was on the verge of welfare, but never reconciled that fact with his asserted need for precision. Currie, supra note 2, at 760 .

74. However, a single accident's effect on the size of a welfare budget is insignificant. Or, at least, so the interest analysts have responded to arguments regarding the increased insurance costs of compensatory policies; they claim that the price of a single catastrophic accident is absorbed by the loss-spending mechanism, not passed on. Currie EssaYs, supra note 1, at 724-25, 725 n.118 (citing Morris, Enterprise Liability and the Actuarial Process - The Insignificance of Foresight, 70 YALE L.J. 544, 565 (1961)); see Ehrenzweig, Guest Statutes in the Conflict of Laws - Towards a Theory of Enterprise Liability Under "Foreseeable and Insurance Laws" (pt. 1), 69 YALE L.J. 595, 603 (1960).

75. At certain points he seemed to realize that complete precision was unattainable and that it was not desirable to look behind the named variable even though it might be a fiction. CURRIE EsSAYS, supra note 1, at 145; Currie, supra note 2, at 760 . But in his analysis of cases 
one should go beyond the mere fact of residence to determine whether the crucial variables support a state interest. This is the only way to account for his attitude toward liability insurance. In analyzing what would have happened if Grant $v$. McAuliffe had been brought in Arizona, Currie argued that the Arizona interest in protecting the tortfeasor's estate "evaporates completely" if the tortfeasor is fully insured. ${ }^{76}$ If the estate would not bear the loss, a court would subvert no Arizona interest whatsoever by applying the California survival statute. ${ }^{77}$ Thus, Currie apparently thought that even if the proxy seems to require application of a law (the tortfeasor was from Arizona, suggesting that we apply the Arizona law), we should look behind it to determine whether the crucial variables also point to that law.

This is surely nothing like ordinary statutory construction. In purely domestic cases, the Arizona courts would not look to the presence of insurance to determine whether the Arizona abatement law should apply. While such an inquiry would be entirely consistent with Currie's reasoning, it is not permissible under any currently held theory of domestic interpretation of statutes. ${ }^{78}$ In fact, the existence of insurance is supposed to be kept as much out of the process of adjudication as can be arranged.

More can be gleaned from this hypothetical variation of Grant than the simple observation that Currie was willing to consider factors that he would have thought illegitimate in a domestic case. We should also notice exactly what triggered this kind of illegitimate inquiry. What facts made it appropriate for Currie to take insurance into account in conflict cases but not in purely domestic cases? The

he commonly cited variables not specified in the statute, ones which would presumably not be important in domestic cases. His treatment of Grant v. McAuliffe, 41 Cal. 2d 859, 264 P.2d 944 (1953), discussed in text at note 22 supra, is one example. See also his evaluation of Home Ins. Co. v. Dick, 281 U.S. 397 (1930), discussed in CuRRIE ESSAYS, supra note 1, at 232-33 (Texas party was only an assignee of original contracting party and thus not entitled to application of Texas law), and of Bradford Elec. Light Co. v. Clapper, 51 F.2d 992 (1st Cir. 1931), discussed in CURRIE EsSAYS, supra note 1, at 210-13 (deceased left no dependents, for whose benefit wrongful death act had been intended).

If interest analysis relies on these "substantive" factors that would not be considered relevant in domestic disputes, it runs into the problems outlined in the text. Even where it relies upon substantive variables that are relevant in domestic cases, it causes courts serious difficulties when alluding to them as justification for applying another state's law. These are spelled out in the text at notes 88-97 infra.

76. CURRIE ESSAYS, supra note 1, at 159-60.

77. Currie qualified this view only by conceding that the Arizona statute might have been designed to protect the insurance industry. In this unlikely event, he thought there might be an Arizona interest in cases involving an Arizona insurance company. Id. at 160.

78. But see Jess v. Herrmann, - Cal. 3d -, 604 P.2d 208, 161 Cal. Rptr. 87 (1979) (mandatory set-off rule not applicable in comparative fault setting where parties are insured). 
only multistate connecting factor that Currie thought an Arizona court should find relevant was the tortfeasor's residence. Yet that could not have been the triggering factor, for in both the purely domestic case and in Currie's hypothetical the tortfeasor was from Arizona. No, other multistate elements in the case must have led Currie to perceive the dispute as a conflicts case and thus to apply this unusual mode of reasoning. In particular, Currie must have perceived this variation of Grant (with its Arizona tortfeasor carrying Arizona insurance) as a conflicts case because the plaintiff was a nonresident plaintiff, the accident took place out of the state, or something of that sort. Yet such elements are supposed to be formally irrelevant within Currie's theory.

It is easy enough for present day interest analysts to avoid such an embarrassing result by denying that it is ever appropriate to look behind the fact of residence to determine whether there are local creditors, whether the defendant was insured, or whether either the plaintiff or the defendant is likely to end his days on welfare. ${ }^{79}$ But if interest analysis does not look behind the domiciliary factor to these supposedly crucial variables, then it falls prey to the same objections Currie made to the Bealean system. It treats one crude geographical factor as talismanic.

In effect, the interest analysts have made three incompatible claims for their theory:

1) The legislative policy responsible for restricting the benefit of protective and compensatory laws to residents is a policy of avoiding dissipation of state welfare resources;

2) Interest analysis, unlike Bealean theory, allows precise case-bycase enforcement of legislative policies; and

3) Interest analysis is just like ordinary statutory interpretation in a purely domestic setting.

As we have seen, these three claims cannot all be correct. Currie tried to remain faithful to the first two in his discussion of Grant but was left with a clear contradiction of the third. Present day analysts who cling to the first and third claims must abandon the key second

79. The Supreme Court has indicated, in support of this position, that excessive particularization is uncalled for. See Carrol v. Lanza, 349 U.S. 408, 413 (1955). Currie realized the Court's view, but never took it into account. See CURRIE EsSAYS, supra note 1, at 145 n.64. See also Barret v. Foster Grant Co., 450 F.2d 1146, 1153 (1st Cir. 1971):

Plaintiff argues that New Hampshire has a "strong legislative policy" at stake in this case in that the New Hampshire legislature has expressed an intention that its workmen's compensation act not bar suits against tortious third parties. . . . Plaintiffs further assertion that New Hampshire law should control "because plaintiff was the sole support of five minor children" is not only a jury argument, but an improper one at that. We cannot believe that a rule of conflict of laws is to depend upon the affluence, vel non, of the parties. 
claim. The best alternative is to renounce the first claim and to search for another justification for interest analysis as a species of constructive intent. 80

A third defense of parochialism might be that restricting benefits to residents is not unfair since a nonresident should not complain of being held to his own state's law. ${ }^{81}$ Thus, when the state of residence of a defendant-driver decides not to enact a guest statute, it indicates a willingness to have its residents pay such claims. This justification raises issues of reciprocity. The nonresident is held to his state's law when it imposes a burden, but cannot recover under that law when he attempts to reap its benefits in a suit against a forum resident. It makes more sense to view the other legislature's decision not to enact a guest statute as a compromise - a regulation of the legal relationship between drivers and passengers. The extra burdens a guest statute imposes on plaintiffs are justified by corresponding advantages to defendants and to the insurance-buying public; a given individual may as easily end up on the plus side as on the minus. The legislature of a state without a guest statute probably did not intend to burden its residents when they drive without allowing them benefits when they ride along.

Interest analysis projects into multistate cases the other legislature's willingness to have its residents pay claims but fails to consider its own demonstrated willingness to have the injured guest go uncompensated. If interest analysis respected such a legitimate "noncompensatory" policy, it would apply the forum guest statute and deny recovery. Instead, the interest analysts would have the forum court make a very curious sort of concession to other states: "Yes, we realize that you prefer to see your rule of decision applied. You

80. These three claims might, in fact, all be incorrect. Much tort law could not have been designed to protect the welfare rolls since it predated welfare legislation. Rather it reflected a sense of who ought to bear the cost of particular accidents. Whether one defines "ought" in terms of ethics or economics, compare R. POSNER, ECONOMIC ANALYSIS OF LAw (2d ed. 1972) ("ought" in terms of economics), with R. DwORKIN, TAKING RIGHTS SERIOUSLY (1977) ("ought" in relation to the general welfare), plaintiff's residence attains no particular relevance as it might with a welfare rationale. In addition, "precision" is not pursued singlemindedly even in purely domestic cases. The very act of codification - of selecting one group of factors out of a large variety of possible relevant ones - entails some sacrifice of precision. See Powers, Formalism and Non-formalism in Choice of Law Methodology, 52 WASH. L. Rev. 27 (1976). See generally Kennedy, Form and Substance in Private Law Adjudication, 89 HARv. L. REv. 1685 (1976). In domestic cases this loss of precision is justified in part by increased predictability and ease of administration. Thus, to the extent that interest analysis downgrades these values, it ceases to resemble ordinary methods of interpretation. See Twerski \& Mayer, Toward a Pragmatic Solution of Choice of Law Problems - At the Interface of Substance and Procedure, 74 Nw. U. L. REv. 781, 790 (1979) (in domestic case, individualized justice subordinated).

8i. Currie Essays, supra note 1 , at 720. 
think it the best way to decide cases. Our compromise will be to apply the rule of decision you find appropriate in some, but not all, cases: exactly those cases in which your rule would work to the advantage of a resident of our state." This is obviously not much of a concession. As a justification for the inherent inequity in selectively deferring to the laws of a nonresident's home state it is disingenuous at best.

A final justification for the interest analysts' belief that legislatures are or should be parochial might be that such legislatures are predisposed to line the pockets of their constituents. From a purely abstract standpoint, such a predisposition is at least coherent. Perhaps it is even plausible. It is, however, an impermissible basis for a conflict-of-laws theory. In commerce clause cases, the Supreme Court has consistently held naked preference for local commercial enterprise to be invidious. For example, in Baldwin v. Seeligs2 the Court invalidated a New York statute prohibiting the sale of milk for less than a fixed minimum price, even if the milk was originally purchased outside the state. The statute, the Court held, could not be justified as an economic measure designed to protect local farmers from competition, since such favoritism is impermissible. ${ }^{83}$

A conflicts methodology based only on favoritism for local residents would surely run counter to the established principles of the American federal system. ${ }^{84}$ It seems directly contrary to the spirit of the privileges and immunities clause and the equal protection

82. 294 U.S. 511 (1935). See generally Simson, State Autonomy in Choice of Law: A Suggested Approach, 52 S. CAL. L. REv. 61 (1978); Simson, Discrimination Against Nonresidents and the Privileges and Immunities Clause of Article IV, 128 U. PA. L. Rev. 379 (1979); Note, Unconstitutional Discrimination in Choice of Law, 77 ColUM. L. REv. 272 (1977). The extent to which this rationale can rely upon political underrepresentation is in doubt after Holt Civic Club v. City of Tuscaloosa, 439 U.S. 60 (1978) (individual residents of outlying unincorporated community do not have constitutionally guaranteed right to vote in municipal elections, despite municipality's power to regulate).

83. More recent cases have reaffirmed the Baldwin result. See Dean Milk Co. v. City of Madison, 340 U.S. 349 (1951); Polar Ice Cream \& Creamery Co. v. Andrews, 375 U.S. 361 (1964) (principles of Baldwin "as sound today as they were when announced").

In Baldwin, New York had attempted to justify the statute as a health measure, arguing that the dairy farmers' health was endangered if they could not make a living. This argument seems curiously to anticipate the "social welfare" justification of interest analysis discussed immediately above. See text at notes 73-74 supra. Yet the Court rejected the argument:

Economic welfare is always related to health . . . . Let such an exception be admitted, and all that a state will have to do in times of stress and strain is to say that its farmers and merchants and workmen must be protected against competition from without, lest they go upon the poor relief lists or perish altogether ... . The Constitution was framed under the dominion of a political philosophy less parochial in range.

294 U.S. at 523 (1934). See also Simson, State Autonomy, supra note 82.

84. For instance, prejudice against out-of-staters was an original motivation for the establishment of diversity jurisdiction. See C. WRIGHT, FEDERAL CourTs 85 (3d ed. 1973). 
clause. ${ }^{85}$ The point is not that any statute that incidentally favors local residents (or any conflict-of-laws method that does likewise) is unconstitutional. The point is that the increased advantages for state residents at the expense of outsiders cannot serve as a justification. There must be some other legitimate rationale for the rule. ${ }^{86}$ The interest analysts have yet to present one. ${ }^{87}$

\section{Are Substantive Policies Enough?}

Underlying the analysis of governmental interests is the assumption that conflict-of-laws reasoning is no different from ordinary substantive interpretation of statutes. In both cases, the job is allegedly to determine whether the policies behind the statute make the statutory remedy appropriate. in the particular case. Therefore, it makes no sense to say that a law "applies" apart from the sense that its substantive policies "apply." 88 In this Section, I will argue that there are two very different meanings to the word "apply," and that they cannot be equated, even if one is committed to Currie's theory. One is the domestic meaning, asking whether the statute's policies are satisfied; the other is the conflicts meaning, asking whether the rule of decision supplied by the statute is pertinent. By analyzing examples taken from the section on parochialism, I hope to show that domestic interpretation and conflicts interpretation are different enterprises altogether.

The first example is based upon the guest statute cases. Currie argued that a state with a guest statute has an interest in applying that statute only in suits against a resident defendant. But what hap-

85. See Simson, State Autonomy, supru note 82; Simson, Discrimination, supra note 82. Currie demonstrated some awareness of this problem. See, e.g., CURRIE ESSAYs, supra note 1, at 619 . See also note 21 supra.

86. Many statutes provide different substantive results depending on the fact of residence. See Simson, State Autonomy, supra note 82; Simson, Discrimination, supra note 82. These, perhaps, provide the strongest support for the suggestion that legislatures would treat residents more favorably than nonresidents when choosing whether their law should apply. However, an established principle of statutory interpretation is to avoid constructions that exacerbate constitutional infirmities. If courts interpret state legislation on the theory that it is designed to benefit locals at the expense of out-of-staters, they are choosing, instead, the most provocative interpretation.

87. Perhaps at the root of the restriction of benefits to state residents is the fact that when it enacted protective or compensatory legislation, the legislature "had in mind" cases where a resident would benefit. The legislator voting for a guest statute, for example, visualizes cases with a resident defendant. However, this mental picture undoubtedly also featured à resídent plaintiff - as well as an accident which occurred within the state. A too literal fidelity to what the legislature "had in mind" ultimately leads to the conclusion that forum law should not apply in cases with any multistate elements.

88. Currie consistently argued that interest analysis was identical to substantive policy analysis of whether the law applied. See CuRRIE EsSAYs, supra note 1, at 183; Currie, supra note 2 , at 757 . 
pens, for an interest analyst, if the state repeals its guest statute? The repeal is undoubtedly "for the benefit" of state residents, helping resident guests to be better compensated for their injuries. Would an interest analyst therefore limit the repeal's application to cases where a resident thereby benefits? That would leave the guest statute standing when a nonresident guest sues a resident driver, and surely such a result would be absurd. Members of the Currie school would agree that the territorial reach of the repeal must be identical to the territorial reach of the original statute. But if the scope of the guest statute is defined in terms of benefiting residents, the repeal must perversely work to the residents' disadvantage. ${ }^{89}$

More generally, interest analysis shifts the geographical reach of forum law as substantive law is first enacted and then repealed. The boundaries of forum law shift in ways that the Currie school would find hard to explain in terms of substantive policies alone. These fluctuations may be illustrated with a matrix. Since Currie felt that the domiciles of the two parties were the only relevant features in guest statute cases, only a two-by-two matrix is required.90 In the matrix below, which represents all two-party cases that might be brought in the forum's courts, the upper left rectangle represents the purely domestic cases; the lower right rectangle the purely foreign cases; the upper right rectangle the cases where the defendant is a resident and the plaintiff a nonresident; and the lower left rectangle the cases where the plaintiff is a resident and the defendant a nonresident.

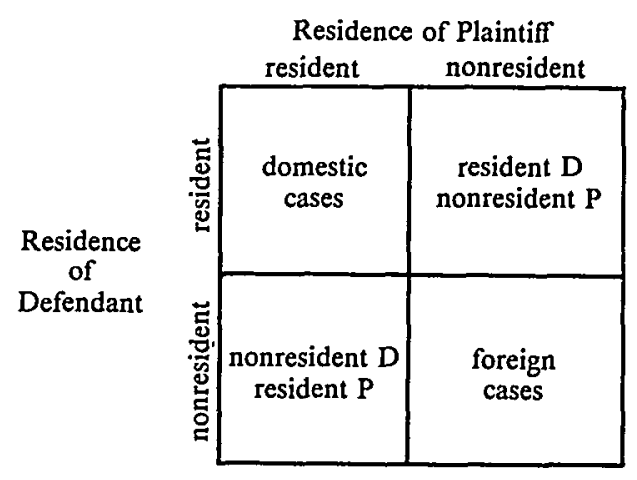

Diagram A

89. A similar argument might be made that if a statute creates a new defense for an old cause of action, it probably intends that defense to apply to all cases involving the original cause of action, although the conclusion is less obvious than in the repeal context. The idea would be that it "repeals" the statute in a substantively specified group of cases, not just where the resident would benefit by application of the defense. This argument could be used regarding guest statutes.

90. While Currie also took forum into account in his diagrams depicting married women's contracts, these matrices reflect only cases in a particular forum. 
For an interest analyst, the cases in the left half of the matrix will trigger any forum interest in advancing a compensatory policy, and those in the upper half will trigger any interest in advancing a protective policy. The domestic cases are covered whether compensatory or protective policies are involved, and the foreign cases are not. These domestic and foreign cases pose no conflicts issues.

Interests Generated

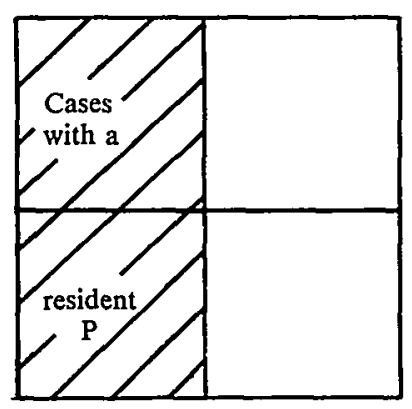

Compensatory Policy

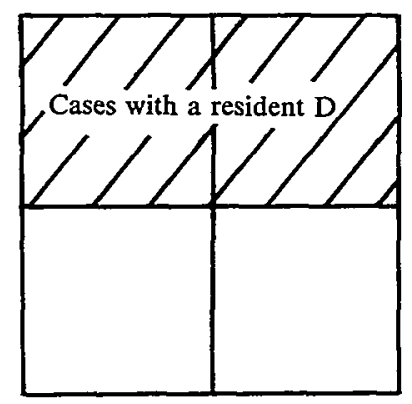

Protective Policy

Diagram B

Before a state enacts a guest statute, its negligence laws presumably promote a compensatory policy. Thus, over the period of time during which its substantive policies change, the forum law's intended scope fluctuates in the following manner:

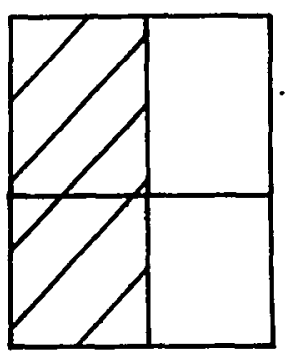

before enactment

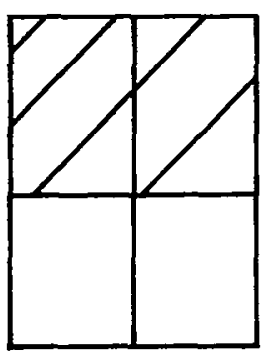

during

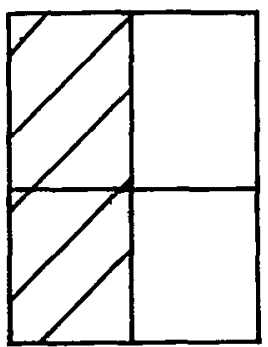

after repeal

Diagram C

We have already seen one problem with this conception of interests: a repeal must apply to all cases previously covered by the statute, including those cases in the upper right corner of the matrix. It is entirely reasonable to say that the repeal has both conflicts and 
substantive implications for the cases in the lower left corner, but only conflicts implications for those in the upper right corner. The repeal could be said to entail a lack of concern with this last group of cases, referring the forum court to the laws of other concerned jurisdictions.

But this intent to disavow any interest in that group of cases cannot be explained in terms of benefiting forum residents, for it probably does not have that effect. Indeed, it cannot be explained as a substantive policy at all, for the legislature has no substantive wish for those cases. Rather, it resembles a traditional choice-of-law rule - an "odd creature" in Currie's words "which never tells us what the result will be but only where to find the result."91 Thus, in passing laws, a legislature necessarily makes conflicts decisions, even under the Currie analysis. Some laws have implications for the territorial reach of forum law that cannot be explained in substantive terms.

That legislatures have - indeed, must have - such unsubstantive intent at times does not necessarily jeopardize any particular conclusions Currie might have reached about when a forum should apply its own law; rather, in this instance, it derives from them. But while this particular nonsubstantive intent is not threatening, generalized searching for nonsubstantive intentions regarding a statute's scope might lead a court to different conclusions than Currie's methodology would dictate. A court might, for instance, discern a legislative intent that the law of the place of wrong should govern, therefore refusing to apply forum law even though interest analysis would deem the law's substantive policies satisfied. Or it might use forum law to settle cases that did not fulfill Currie's interpretation of the statute's substantive policy. Currie found this last possibility absurd, insisting that a law "applied" if and only if the substantive policies underlying it applied. ${ }^{92}$

Currie was demonstrably mistaken on this point. His attempts to treat geographical connecting factors in exactly the same way that ordinary domestic factors are treated were doomed to failure. Apparently, the idea was that for any particular statute, some geographical connecting factors would be relevant and some would not, just as some facts that might be found in local cases are relevant and

91. CuRrie Essays, supra note 1, at 170. Compare also his remark that "a choice-of-law rule is an empty and bloodless thing. Actually, instead of declaring an overriding public policy, it proclaims the state's indifference to the result of the litigation." Id. at 53 .

92. For instance, he derided the public policy exception because it provided "a basis for not applying the 'applicable' law." CURRIE EsSAYS, supra note 1, at 181, 212, 736. 
some are not. In both domestic and conflicts cases, the court's job is supposedly to identify the necessary preconditions for the result specified in the statute. In a domestic guest-statute case, a court might have to decide whether it was relevant that compensation was offered and thus whether failure to pay was a prerequisite for application of the guest statute. ${ }^{93}$ Similarly, in a multistate case, Currie would have the court consult the underlying policies to determine whether it was relevant that the accident occurred in another state. In Currie's view, the substantive and conflicts prerequisites for using the guest statute to require a showing of reckless misconduct were not qualitatively different.

The fallacy in this idea can be illustrated by classifying cases according to three criteria: a) whether the relevant substantive preconditions for domestic law are satisfied, b) whether the supposedly relevant conflicts preconditions for domestic law are satisfied, and c) whether there are any other elements that link the case with a foreign state but that Currie would have declared irrelevant. Consider a case where the substantive criteria are satisfied, the conflicts criteria are not satisfied, and there are no other multistate connecting factors in the case. Does the forum legislature intend its law to apply?

It seems the interest analysts would say that forum law should not apply. The crucial conflicts test has not been met. The fact that all other connecting factors point toward domestic law is by hypothesis irrelevant. Interest analysts would presumably also say that this case is indistinguishable from one where the substantive test is satisfied, the conflicts test is not satisfied, and all the "irrelevant" connecting factors point toward the other state's law. The reason is precisely that other connecting factors are supposed to be irrelevant. To express this point diagramatically, the argument is that cases (1) and (2) are equivalent:

\begin{tabular}{lcc} 
substantive test & conflicts test & $\begin{array}{c}\text { irrelevant } \\
\text { connecting factors }\end{array}$ \\
\hline (1) satisfied & foreign & all foreign \\
(2) satisfied & foreign & all domestic
\end{tabular}

But the interest analysts claim that conflicts preconditions are just like substantive preconditions. Since there is no difference between the two sorts of variables, a failure to satisfy one should have the same result as a failure to satisfy the other. ${ }^{94}$ Therefore, cases (2)

93. See, e.g., W. Prosser, HaNdBook of the LAW of TorTs 382-85 (4th ed. 1971).

94. See, e.g., Currie's treatment of Bradford Elec. Light Co. v. Clapper, 286 U.S. 145 
and (3) are identical:

\begin{tabular}{|c|c|c|}
\hline substantive test & conflicts test & $\begin{array}{c}\text { irrelevant } \\
\text { connecting factors }\end{array}$ \\
\hline $\begin{array}{l}\text { (2) satisfied } \\
\text { (3) not satisfied }\end{array}$ & $\begin{array}{l}\text { foreign } \\
\text { domestic }\end{array}$ & $\begin{array}{l}\text { all domestic } \\
\text { all domestic }\end{array}$ \\
\hline
\end{tabular}

However, if (1) and (2) are identical, and (2) and (3) are identical, then so are (1) and (3). Yet (1) is a foreign case, with no domestic aspects at all, and (3) is a domestic case, with no multistate elements. Surely, if there is anything that all conflict-of-laws theorists would agree upon, it is that the legislature intends its law to apply to (3) and not to (1)..$^{95}$

The problem that leads to this paradox is the assumption that conflicts preconditions are just like substantive preconditions, that is, that case (2) is identical to case (3). This assumption leads the interest analysts to conclude that a case's failure to meet a statute's substantive preconditions will keep the state from finding an interest, presumably even if the "crucial" conflicts variable points toward forum law. In cases with other multistate features, that conclusion is difficult to refute since we have no clear evidence about legislative intent; but in a purely domestic case, it is clearly false. Moreover, the only factors that the interest analysts might employ to distinguish between those two classes of cases are multistate features that are supposed to be irrelevant. ${ }^{96}$ If we assume that those features are indeed irrelevant, then we must abandon the prior assumption that conflicts preconditions are just like substantive preconditions.

In truth, there is no reason why substantive requirements should be like conflicts requirements. Failure to satisfy the substantive requirements of forum law does not in domestic cases provide a reason for turning to the law of another state; nor does it mean that the forum no longer wants to use its own rule of decision. The paradox outlined above arises because the interest analysts have lumped to-

(1932), in which he concluded that New Hampshire had no interest and Vermont law should apply because the substantive preconditions for application of the wrongful death statute were not satisfied. Currie EsSAYs, supra note 1, at 210.

95. In precisely the same way, it can be demonstrated that a fourth case: substantive test, not satisfied; conflicts test, domestic; irrelevant connecting factors, all foreign; is equivalent to both (1) and (3).

96. This anomaly is similar to the problem that arose from Currie's treatment of insurance. See text at notes 76-77 supra. In cases with a variety of multistate elements, Currie asserted that facts such as the existence of insurance might be relevant to the satisfaction of substantive criteria, and thus defeat an interest based on a defendant's residence. Yet in purely domestic cases courts would never consider insurance. 
gether two different uses of the word "applies." They argue that if a conflicts prerequisite is not met, the statute fails to apply in the same sense as when a substantive prerequisite is not met. But in a purely domestic case, domestic law "applies" under any conflict of laws theory; the word means that domestic law supplies the pertinent rule of decision. Once we "apply" that law, however, the issue may go either way, depending upon whether the substantive preconditions are satisfied. In the conflicts-of-laws sense, a domestic guest statute "applies" to all domestic accidents; but in the substantive sense of prohibiting recovery, it "applies" in only some of those cases, namely those in which the driver was not compensated. To say that a standard applies may mean either that it is pertinent, or that it is satisfied.

Interest analysts have attended only to the latter use of the word. Yet a single meaning is necessarily insufficient. At least three different situations require different treatment: the purely domestic case with all substantive preconditions satisfied, the purely domestic case with some deficiency in the substantive preconditions, and the purely foreign case. To insist on only one meaning, and therefore only one test, forces cases in the middle category to be treated as falling into either the first group or the third group. But they are not identical to the first, since they require a different substantive outcome. Nor should they be equated with the third group, since purely domestic cases call for domestic law and purely foreign cases call for foreign law. A two-step inquiry about the pertinence of the standard and then about whether it is satisfied, would give cases in the middle group the special treatment they deserve. If forum law is pertinent, the second step is to apply it, thus dividing the group to which the forum law applies into two more groups: those that satisfy the standard and those that do not.

Courts resolve problems involving both state and federal law by using this same two-stage process. The decision about whether federal law supplies the rule of decision is independent from and prior to the decision about what substantive result is appropriate. ${ }^{97}$ This method is particularly clear where a federal question is the only basis for subject matter jurisdiction; the jurisdictional issue is decided before the substantive issue. A subsequent finding that the federal law's substantive purposes do not mandate recovery does not make that law any less dispositive; the court need not then turn to state law or dismiss for want of jurisdiction.

97. Cf. Suchomajcz v. Hummel Chem. Co., 524 F.2d 19 (3d Cir. 1975) (court made its conflict-of-laws decision before passing on the merits of a disputed substantive issue). 


\section{Actual Legislative Intent Revisited: A Glance at Selected Statutes}

The traditional methodology aspired to predictability, simplicity, and evenhandedness. The interest analysts claim that these methods risked sacrificing substantive policy goals in the process. Interest analysis, in contrast, allows parochial, unpredictable, and chaotic results. Nonetheless, the interest analysts argue, the results are at least faithful to legislative wishes. And Currie's confidence that state legislatures would agree with him was remarkable. At one point he wrote:

[There] is [a] growing tendency of legislators to specify how their enactments are intended to affect mixed cases. The task of drafting such provisions forces attention to the interests and objectives involved. $A$ legislature is not likely to append to any statute dealing with a specific problem any such rule as that the law of the place where the contract is made shall control.98

Even a casual glance at choice-of-law statutes shows that he was wrong. Existing choice-of-law statutes demonstrate that simplicity, predictability, and multistate harmony motivate state legislatures just as they have motivated all conflicts theorists except the interest analysts.99 Indeed, given the two senses of the word "applies," this is entirely sensible. In enacting a substantive statute, the legislature considers the competing substantive claims on both sides and strikes a balance. In drafting a conflicts provision to accompany it, the legislature must choose between making its own standards pertinent or referring to the law of other states. Again, a balance must be struck: but the substantive values were already accommodated in the first decision. The other decision - about when to make the statute pertinent - reflects values such as comity and predictability.

In the statutes cited below, explicit legislative adoption of the Currie school methods seems to be lacking. Almost wholly absent, for example, is support for the premise that compensatory and protective policies are designed to benefit only forum residents. If Currie's inferences about legislative intent were correct, this premise would be reflected in two ways. First, statutes motivated solely by a protective or compensatory policy would limit their own scope to cases where the forum rule would benefit a resident. Second, when

98. CURRIE ESSAYS, supra note 1, at 116 (emphasis added). Cf. id. at 703: "In any realistic setting...., we are likely to find that the concern of the state is with the people involved rather than the scene of the activity."

99. For a survey and discussion of choice-of-law statutes, see W. REESE \& M. ROSENBERG, Conflict of Laws 553-56 (7th ed. 1978); Leflar, supra note 3. 
such policies were conjoined with regulatory policies in a single statute, they would supply an alternative ground for its application.

Instead, a search through conflict-of-laws statutes reveals mostly Bealean conflicts rules. We find statutes that make the rule of lex loci govern the permissible interest on loans, ${ }^{100}$ statutes that make forum law apply to all torts or crimes committed in airplanes over forum territory, ${ }^{101}$ and statutes that make the law of the place of execution or performance govern interpretation of wills. ${ }^{102}$ None of these statutes is phrased in terms of benefiting forum residents, although many serve protective or compensatory purposes. The effect on forum residents is never mentioned as either a sole or an alternative basis for applying forum law. Other conflict-of-laws statutes establish the relevance of different geographical factors, but also in the style of traditional conflicts rules: certain securities problems are to be decided according to the law of the issuer's residence, ${ }^{103}$ mergers are controlled by the law of the state where the survivor is incorporated, ${ }^{104}$ and bank deposits are governed by the law of the bank's

100. See, e.g., Ga. Code ANN. § 57-106 (Harrison 1977); Mich. Comp. Laws § 438.154 (1970); Neb. REv. STAT. § 45-158 (1978).

101. See Ariz. Rev. Stat. ANN. \& 28-1704 (1976); Mich. Comp. Laws \& 259.177 (1970); N.C. Gen. Stat. § 63-16 (1975); PA. Stat. ANn. tit. 2, § 1470 (Purdon 1963).

102. See Ariz. Rev. Stat. AnN. $\$ \S 14-2506$ (1975), 14-2602 (Supp. 1979); Cal. Civ. Code $\S 1646$ (West 1973); Cal. Civ. Proc. Code $\$ 1857$ (West 1955); Cal. Prob. Code $\S 26$ (Deering 1974); Del. Code ANN. tit. 12, \& 1306 (Supp. 1978); LA. Civ. Code ANN. art. 10 (West 1952); LA. Code Civ. Pro. ANN. art. 2888 (West 1961); Mass. ANN. LAws. ch. 191, § 1A (Michie/Law Co-op. Supp. 1979); Mich. Comp. Laws ANN. $\& 700.133$ (West Supp. 1979). Neb. Rev. Stat. \$30-2340 (1975); N.D. Cent. Code § 30.1-08-06, -09-02 (1976); OR. Rev. STat. \& 112.230, .255 (1977); S.D. Comp. Laws ANN. § 53-1-4 (1967); Wis. Stat. ANN. $\S 853.05$ (West 1977).

103. See Ala. Code § 7-8-106 (1975); ARIz. Rev. Stat. ANN. § 44-3006 (I967); ARK. Stat. ANn. § 85-8-106 (1961); CAL. Com. Code § 8106 (West 1964); Colo. Rev. STAT. § 4-8106 (1973); ConN. GeN. STAT. ANN. \& 42a-8-106 (West 1960); Det. Code tit. 6, \& 8-106 (1974); FLA. STAT. ANN. § 678.8 -106 (West 1966); ILl. ANN. STAT. ch. 26, § 8-106 (Smith-Hurd 1974); IOWA CODE ANN. \$ 554.8106 (West 1967); KAN. STAT. ANN. \$ 84-8-106 (1965); KY. REV. STAT. § 355.8-106 (1970); ME. Rev. Stat. ANN. tit. 11, § 8-106 (1964); MD. CoM. LAw. Code ANN. § 8-106 (1975); Mass. ANN. Laws ch. 106, § 8-106 (Michie/Law Co-op. 1976); Mich. Comp. Laws § 440.8106 (1970); MinN. STAT. § 336.8-106 (West 1974); Miss. Code ANN. § 758-106 (1972); Mo. Rev. Stat. § 400.8-106 (1969); Mont. Rev. Codes ANN. § 87a-8-106 (1947); Neb. Rev. Stat. U.C.C. § 8-106 (1971); Nev. Rev. STAt. \& 104.8106 (1973); N.H. Rev. STAT. ANN. \& 382A:8-106 (1961); N.M. STAT. ANN. § 55-8-106 (1978); N.C. GEN. STAT. § $25-$ 8-106 (1965); Ohio Rev. Code AnN. \$ 1308.05 (Page 1979); OKLA. Stat. AnN. tit. 12a, \& 8106 (West 1963); OR. Rev. Stat. \$ 78.1060 (1973); PA. STAT. AnN. tit. 12A, § 8-106 (Purdon 1970); R.I. GEN. LAwS § 6A-8-106 (1969); S.C. CODE § 36-8-106 (1976); S.D. CoMP. Laws ANN. § 57-31-19 (1967); TENN. CODE ANN. § 47-8-106 (1979); TEX. Bus. \& COM. CODE ANN. tit. 1 , $\$ 8.106$ (Vernon 1968); UTAH CODE ANN. \& 70A-8-106 (1979); VA. CODE \$ 8.8-106 (1965); Wash. Rev. Code § 62A.8-106 (1966); W. VA. Code § 46-8-106 (1966); WIS. STAT. § 408.106 (1977); WYO. STAT. ANN. \& 34-21-806 (1977).

104. See Alaska Stat. $\$ 10.05 .408$ (1968); Cal. Corp. Code $\S 1108$ (West 1977); Colo. Rev. Stat. § 7-7-107 (1973); Conn. Gen. Stat. AnN. \& 33-482 (1960); ME. Rev. Stat. ANn. tit. 13-B, \& 906 (1977); Nev. Rev. STat. \& 78.475 (1977); N.M. Stat. ANN. \& 53-14-7 (1978); N.Y. Not-For-Profit Corp. LAw § 908 (McKinney 1970); N.C. Gen. Stat. §55A-42.1 
location. ${ }^{105}$

Even when a conflict-of-laws statute relies on a party's residence, we do not find the parochialism Currie anticipated. Connecticut determines the status of children born after artificial insemination by the law of the place of birth, but it apparently does not matter whether the child would be helped or harmed by Connecticut law on the subject. ${ }^{106}$ The Uniform Probate Code determines spousal elective share by reference to the law of the parties' residence, but apparently either a resident or a nonresident may invoke that law, whoever would benefit by having it applied. ${ }^{107}$

We also find the familiar "alternative reference" rules, which uphold wills or contracts if they would be valid under the law of any one of several states (state of making, state of execution, etc.). ${ }^{108}$ No doubt legislatures adopt these rules to vindicate reasonable expectations. But once again, they make no mention of who will benefit under any of the laws in question. ${ }^{109}$ A number of conflicts statutes

(1975); Ohio Rev. Code ANN. \& 1701.79 (Page 1978); Pa. Stat. AnN. tit. 40, \& 459a (Purdon 1971); TEX. Bus. CoRP. CODE ANN. art. 5.07 (Vernon 1956); UTAH CODE ANN. $\$ 16-10-72$ (1953); VA. CODE § 13.1-71 (1978); WASH. REV. CODE § 23A.20.070 (1969); W. VA. CODE § 31-1-38 (1975); WIS. STAT. \& 180.68 (1977); Wyo. STAT. ANN. \& 17-1-406 (1977).

105. See Ala. Code § 7-4-102 (1975); ARIz. Rev. Stat. AnN. § 44-2602 (1967); ARK. STAT. ANN. \& 85-4-102 (1971); Del. CODE ANN. tit. 6, \& 4-102 (1974) (Delaware annotations to this provision cite the Restatement with approval); FLA. STAT. ANN. \& 674.4-102 (1966); ILL. Rev. STAT. ch. 26, § 4-102 (1963); IOWA CODE ANN. § 554.4102 (1967); KAN. STAT. ANN. § 844-102 (1965); LA. Rev. STAT. ANN. § 10:4-102 (West Supp. 1978); ME. Rev. STAT. ANN. tit. 11 , § 4-102 (1964); MD. CoM. LAw Code ANN. § 4-102 (1975); Mass. ANN. Laws ch. 106, § 4-102 (Michie/Law Co-op 1976); MINN. STAT. § 336.4-102 (1966); Miss. CODE ANN. § 75-4-102 (1977); Mo. Rev. Stat. § 400.4-102 (1969); MonT. Rev. Codes ANN. § 87A-4-102 (1947); Neb. Rev. Stat. § 4-102 (1971); Nev. Rev. Stat. § 104.4102 (1973); N.H. Rev. Stat. ANN. § 382-A:4-102 (1961); N.M. STAT. ANN. § 55-4-102 (1978); N.C. GEN. STAT. § 25-4-102 (1975); Ohio Rev. Code ANN. § 1304.02 (Page 1979); OKLA. STAT. ANN. tit. 12A, § 4-102 (1963); OR. Rev. Stat. \$ 74.1020 (1977); PA. Stat. ANN. tit. 12A, \& 4-102 (Purdon 1970); R.I. Gen. Laws § 6A-4-102 (1969); S.C. CODE § 36-4-102 (1976); TEX. Bus. \& CoM. CODE ANN. tit. 1, § 4.102 (Vernon 1968); UTAH CODE ANN. § 70A-4-102 (1953); VA. CODE § 8.4-102 (1950); WASH. REV. CODE § 62A.4-102 (1966); W. VA. CODE § 46-4-102 (1966); WIS. STAT. § 404.102 (1977); WYO. STAT. ANN. \& 34-21-402 (1977).

106. Conn. Gen. Stat. AnN. § 45-69k (West Supp. 1979).

107. See N.D. Cent. Code $§ 30.1-05-01$ (1976); accord, 20 PA. Cons. Stat. ANN. $\$ 2203$ (Purdon Supp. 1979).

108. See Ariz. Rev. Stat. ANN. $\$ \S 14-2506,25-112$ (1975); Cal. Civ. Code $\S 63$ (West 1954); Cal. Prob. Code $\$ 26$ (West Supp. 1979); Del. Code ANN. tit. 12, $\$ 1306$ (1975); IdAho Code § 32-203 (1963); LA. Code Civ. Pro. ANN. art. 2888 (West 1961); N.D. Cent. CODE \$§ 14-03-08, 30.1-08-06 (1976); OR. Rev. STAT. § 112.225 (1977); UtAH Code ANN. § 30-1-4 (1976); Wis. STaT. § 853.05 (1977).

109. But see the discussion of borrowing statutes in notes 113-16 infra and accompanying text. Some examples of statutes that do not mention who will benefit include:

Rules that real property may be governed by the law of the situs. CAL. Civ. Code $\$ 755$ (West 1954); N.D. CENT. CODE § 47-04-01 (1978); S.D. CoMP. LAwS ANN. § 43-1-6 (1967).

Rules that personal property may be governed by the law of domicile. CAL. Civ. CoDE 
explicitly mention the "conflicts rules" of other jurisdictions, 110 thus approving renvoi, a practice Currie found irrational.111 Legislatures also typically define personal jurisdiction by facts such as location of the accident, ${ }^{112}$ finding that factor relevant to whether the state has an interest in adjudicating the case. Statutes of limitation also define willingness to adjudicate by whether the cause of action arose within the state. Where will such irrationality stop?

Perhaps the only example of a statute reflecting Currie's views is the borrowing statute, which allows residents but not nonresidents to take advantage of a forum statute of limitations that is longer than the statute that would otherwise apply. ${ }^{13}$ However, borrowing statutes are intended primarily to prevent forum shopping, a goal the Currie school does not consider important. ${ }^{14}$ If there were no such provision, many courts would always apply the forum statute of limitations $^{115}$ and this might draw litigants to a forum with a long statute. The borrowing statute prevents forum shopping but allows forum law to apply when there is no danger - when the cause of action accrued in the forum or the plaintiff is a resident. ${ }^{116}$

$\S 946$ (West 1954); IDAHO CODE $§ 55-401$ (1979); N.D. CENT. CODE $\$ 47-07-01$ (1978); S.D. COMP. LAWS ANN. \& 43-1-7 (1967).

Rules that marital property may be governed by the law of the state where acquired. ARIz. REV. STAT. ANN. § 25-217 (1976).

110. Ariz. Rev. Stat. Ann. § 44-3006 (1967); Conn. Gen. Stat. Ann. § 42a-8-106 (West 1960); DeL. CODE ANN. tit. 6, \& 8-106 (1975); see statutes cited in note 103 supra.

111. CURRIE EsSAYS, supra note 1, at 184.

112. Other factors, of course, include residence of the defendant, place of incorporation, place of doing business, etc.

113. There are, of course, many statutes which turn on the residence of one party in the substantive sense. See generally Simson, State Autonomy, note 82 supra; Simson, Discrimination, note 82 supra. Such, for instance, are those tolling statutes that specify that the statute of limitations shall not run in favor of nonresidents. See MinN. STAT. ANN. \&541.13 (West Supp. 1979); N.J. Stat. ANN. § 2A:14-22 (West 1952); OKLA. Star. ANn. tit. 12, § 98 (West Supp. 1979); PA. Cons. STAT. ANN. tit. 42, § 5532 (Purdon 1975); R.I. GeN. LAws $§ 9-1-18$ (1970); W. VA. CODE $§ 55-2-17$ (1966); WIS. STAT. ANN. § 893.30 (1974). These are not, however, conflicts statutes since the statutes supply rules of decision regardless of the parties' residence. The statute of limitations does not apply in the substantive sense with regard to nonresidents (because it is tolled), but it does apply in the conflicts sense, because the court does not conclude that there is no interest and then turn to foreign law. As indicated in the accompanying text, this last result has been changed in some states by borrowing statutes; but tolling statutes are not by themselves an exception to the general principle. But see note 86 supra and accompanying text.

114. The purpose of avoiding forum shopping is demonstrated by the common proviso that the resident must have held the cause of action since it accrued. See Cal. Civ. Proc. Code § 361 (West 1954); Kan. STAT. AnN. § 60-516 (1976); Neb. Rev. STAT. § 25-215 (1975); N.C. Gen. STAT. \& 1-2I (1969); UTAH Code ANN. \& 78-12-45 (1953); WIS. STAT. \& 893.205 (1977); cf. Alaska STAT. $\$ 09.10 .220$ (1973); LA. CIV. CODE ANN. art. 3547 (West 1953); OR. REV. STAT. $\$ 12.260$ (1977); WASH. REV. CODE $\$ 4.16 .290$ (1974) (all barring two nonresidents who are injured out of state from using this forum's statute of limitation).

115. Leflar, supra note 3 , at 960.

116. Such borrowing statutes were held constitutional in Canadian N. Ry. v. Eggen, 252 
Interest analysts might offer three explanations for the dearth of statutes reflecting their views. First, they might suggest that these statutes shed no light on what should be done in the absence of a statute, the problem with which Currie primarily concerned himself. They might grant the significance of these laws in the situations explicitly covered, but refuse to extend them by analogy. This response would undercut somewhat their pretensions to "ordinary statutory interpretation," for ordinary statutory interpretation takes advantage of available analogies. Moreover, these statutes demonstrate serious legislative concern with system values, such as predictability and uniformity, in multistate cases.

Perhaps most disturbingly, the Currie school asks us to draw a strange inference from legislative silence. Many substantive statutes were enacted before interest analysis was popular, against a presumption that the applicable rule was "lex loci."117 When conflicts statutes were formulated, they codified that Bealean principle by and large, adapting it where appropriate to reflect new connecting variables, such as place of incorporation for the law of mergers. It seems odd to assume that the legislature intended implicitly to change whatever was not codified and wanted the change to reflect governmental interest. A somewhat more plausible explanation would be that the legislatures left to the wisdom of the courts the decision whether to modify any uncodified territorialist conflicts rules. Even that position is troublesome when used to justify a theory that stresses strict obedience to legislative intent. The most sensible deduction from legislative silence is that the legislature expected everything it took for granted at the time of enactment to remain unchanged.

The second response to the preponderance of Bealean statutes is that legislatures have simply been blinded by territorialist dogma. Many conflict-of-laws statutes are, after all, state-adopted uniform legislation; the drafters of such legislation are undoubtedly pecu-

U.S. 553 (1920). While holding only that the shorter statute of limitations was reasonable, the Court also noted that the plaintiff's sole purpose for selecting the forum was to take advantage of the longer period. 252 U.S. at 563.

117. Historically, it is most probable that legislatures contemplated territorial approaches to conflicts problems. Courts have recognized this legislative predilection when declining to adopt "modern" approaches. See, e.g., Friday v. Smoot, 58 Del. 488, 211 A.2d 594 (1965); Marmon v. Mustang Aviation, 430 S.W.2d 182 (Tex. 1968). After Marmon, the Texas legislature acted to permit application of whichever substantive law the courts think appropriate. Tex. Rev. Civ. STAt. ANN. arts. 4671, 4678 (Vernon Supp. 1976-1977). Texas courts subsequently rejected lex loci and adopted the approach of the Second Restatement in a case that arose between Marmon and the revision of the statute, on the theory that the old statute did not apply to common-law causes of action, and that the new theories were virtually interchangeable. Gutierrez v. Collins, 583 S.W.2d 312 (Tex. 1979). 
liarly susceptible to the charms of predictability and interstate harmony. ${ }^{118}$ This explanation of statutory conflicts rules may be accurate. Even if it is, however, it is not an argument that can be addressed to courts by adherents of a "mine is not to reason why" approach to conflicts. Unless the interest analysts are able to convince state legislators to cast off such "outmoded" and "overly altruistic" inclinations, their hands are tied.

A third explanation is that these apparently territorialist statutes are really entirely consistent with interest analysis. Most of the provisions that refer to the location of activity - such as the one requiring the law of a bank's location to control bank deposits - can be termed "regulatory," making it natural to apply the law of the place where the conduct occurs. But this solution involves an important concession to the traditionalist perspective; it means abandoning concurrent "protective" or "compensatory" policies, and focusing solely on territorial connecting factors. The residence of one party can no longer trigger application of forum law, and interest analysis is thereby made more predictable (as well it should be, especially in matters of commercial law). In short, analysis of governmental interests is made consistent with existing manifestations of legislative intent by rejecting one of the characteristics that distinguish it from traditional analysis: the premise that residents receive favored treatment.

\section{CONCLUSION}

I have adduced a fair number of instances in which principles of interest analysis are contrary to the expressed or reasonably imputed wishes of legislatures. Perhaps this only pushes back the scope of interest analysis to cases where absolutely no legislative intent is demonstrable; perhaps it can still be argued that Currie's principles govern there. This tactic preserves the appearance of consistency with legislative intent, but only by retreating from cases that offer evidence on the question. Moreover, the situations where the interest analysts' imputations of intent are most convincing are precisely those where interest analysis and traditional approaches agree. Currie's most persuasive argument about legislative intent was that a New York rule of the road is not intended to have any application to Saudi Arabia, "but is designed solely to regulate traffic on the streets

118. Currie typed traditionalists as "probably among the strong advocates of uniform state laws." CuRrie ESSAYS, supra note 1, at 708. He also expressed concern that drafters of uniform legislation or interstate compacts would be influenced by settled conflict-of-laws doctrine. Id. at 190 n.5. But see note 63 supra. 
and highways of New York."119

Perhaps by tinkering with the calculus of interest it will be possible to avoid some of the other problems set out in this Article. At a certain point, however, the excessive complexity of a system may cause it to collapse. The Bealean system accommodated itself to larger and larger numbers of more and more serious counter-examples until eventually it was no longer convincing or even intelligible. Interest analysts can hardly cite methodological sponginess, enabling courts to circumvent their method's absurd results, as one of the methodology's virtues. ${ }^{120}$ Currie was quick to make the analogous point when criticizing the First Restatement. ${ }^{121}$

Some may think that this is not tinkering at all, that it is honest development of a single principle: a court should follow legislative intent, and if there is no actual intent, then the court should turn to constructive intent. Interest analysts could then accept this Article's criticisms as a tool to hone their methods. This may even be acceptable, so long as they realize that their talk about "intent" is a fiction and their premises are metaphysical.

It should not be surprising that a theoretical approach to "constructive intent" reflects the value preferences of the theoretician. Where there is no objective evidence, one falls back to one's own conception of the best arrangement. This is particularly likely in conflict-of-laws cases, where evidence of actual legislative intent is rare. Thus in reasoning about conflicts problems, scholars and courts can and should heed some of the values that interest analysts condemned as "metaphysical," such as evenhandedness and predictability. In doing so, a court would not disregard its duty to follow the commands of its legislature. Legislatures, like conflicts theorists, have frequently concerned themselves with systems values. And this is entirely appropriate; respect for these values may benefit residents as well as nonresidents.

When a legislature has not indicated the territorial scope of a

119. CuRrie EsSAYs, supra note 1 , at 58.

120. Currie did not dispute the method's considerable flexibility:

To one of Mr. Hill's charges I plead guilty without reservation. In the first sentence of his essay he attributes to me the proposal that traditional methods of choice of law be abandoned in favor of a method "involving the effectuation of relevant governmental policies on what appears to be an $a d$ hoc basis." "Ad hoc" has a deprecatory connotation that was no doubt intended. But the method I advocate is the method of statutory construction, and of interpretation of common-law rules, to determine their applicability to mixed cases. . . . The distinctive virtue of the common-law system is that it also proceeds on an ad hoc basis. I am proud to associate myself with the common-law tradition. CURRIE EsSAYS, supra note 1, at 627.

121. Id. at 181 . 
statute in either the words enacted or in the legislative history, it is a fiction to speak of "legislative intent." If my analysis of what the calculus of interests requires is erroneous, the interest analysts should clarify the a priori principles upon which their theory necessarily rests. Even better, they would do well to cease making extravagant claims about fulfilling legislators' wishes, and get to work on a theory of constructive interpretation that at least comports with demonstrated legislative concerns. 